\title{
BUDDHIST MODERNISM AND THE RHETORIC OF MEDITATIVE EXPERIENCE*
}

\author{
Robert H. Sharf \\ What we can't say we can't say and we can't whistle either. \\ Frank Ramsey
}

\section{Summary}

The category "experience" has played a cardinal role in modern studies of Buddhism. Few scholars seem to question the notion that Buddhist monastic practice, particularly meditation, is intended first and foremost to inculcate specific religious or "mystical" experiences in the minds of practitioners. Accordingly, a wide variety of Buddhist technical terms pertaining to the "stages on the path" are subject to a phenomenological hermeneutic-they are interpreted as if they designated discrete "states of consciousness" experienced by historical individuals in the course of their meditative practice.

This paper argues that the role of experience in the history of Buddhism has been greatly exaggerated in contemporary scholarship. Both historical and ethnographic evidence suggests that the privileging of experience may well be traced to certain twentieth-century Asian reform movements, notably those that urge a "return" to zazen or vipassana meditation, and these reforms were profoundly influenced by religious developments in the West. Even in the case of those contemporary Buddhist schools that do unambiguously exalt meditative experience, ethnographic data belies the notion that the rhetoric of meditative states functions ostensively. While some adepts may indeed experience "altered states" in the course of their training, critical analysis shows that such states do not constitute the reference points for the elaborate Buddhist discourse pertaining to the "path." Rather, such discourse turns out to function ideologically and performatively-wielded more often than not in the interests of legitimation and institutional authority.

Few would question the pivotal role the category "experience" has played in the modern study of religion. There would appear to be widespread agreement among both phenomenologists and historians of religion that the meaning of many religious doctrines, symbols, and rituals is to be sought in the experiences they evoke in the minds of practitioners. Moreover, a particular mode (or modes) of experience, characterized as "religious," "spiritual," or "mystical," is seen by many to constitute the very essence of religion; indeed, the great traditions are often traced back to the 
"originary experiences" of their founders. It might then seem surprising that so many of the scholars who privilege the category "experience" in the study of religion are apparently hesitant to subject this term to rigorous critical analysis. Even those whose interests lie in the investigation of so-called religious or mystical experience typically devote their efforts to the elucidation of the qualifiers "religious" and/or "mystical," evincing little interest in the analysis of the epistemic commitments entailed in the rhetoric of experience per se.

The notion that the referent of the term "experience" is selfevident betrays a set of specifically Cartesian assumptions, according to which experience is held to be immediately present to consciousness. It would appear that the phenomenological transparency of consciousness-what Richard Rorty has called the "glassy essence" or "mirror of nature" picture of mind (Rorty 1979) - is reproduced in the conceptual transparency of the category "experience," obviating the need for definitional precision or critical analysis.

The strategy of privileging experience on the one hand, while leaving the term unexamined on the other, has proven particularly opportune to those who envision their mission as one of combating the pernicious and ever-present threat of reductionism in the study of religion. By situating the locus of religious signification in phenomenological "inner space," religion is securely sequestered beyond the compass of empirical or social-scientific modes of inquiry. Wayne Proudfoot, who has undertaken an extensive analysis of this particular exegetical strategy, has argued that the category "religious experience" is of relatively recent provenance, and that it was "motivated in large measure by an interest in freeing religious doctrine and practice from dependence on metaphysical beliefs and ecclesiastical institutions" (Proudfoot 1985: xiii). As a consequence of the desire to shield religion from secular critique, the modern study of religion was thought to require the development of specialized hermeneutical tools sensitive to the irreducible experiential foundation of religious phenomena. (This argument has proven particularly popular when legitimizing the existence of departments of religion in publicly funded universities and colleges.) 
The categories of religious experience in general, and mystical experience in particular, were especially influential in the construction of the sub-field of comparative religion. Scholars of religion have been aware of the unavoidable hermeneutical problems involved in applying the Western concept "religion" to traditions that are geographically, linguistically, and culturally distant from our own. The rhetoric of religious experience, predicated as it is on Cartesian dualism, allowed scholars to distinguish the universal experiential ground of religion on the one hand, and its diverse culturally bound manifestations on the other, creating an opposition that recapitulates the classical Cartesian bifurcation of mind and matter.

The Buddhist tradition seemed to support such an analysis, as Buddhist doctrine supposedly distinguished between the ineffable experiential goal of Buddhist practice, and the socially and culturally determined teachings that point toward that goal. According to one popular exegetical strategy, the whole of the Buddhist tradition is not but the attempt to inculcate the experience attained by the Buddha while he sat in meditation under the bodhi tree. Thus, Buddhist ethics, doctrine, art, and ritual ultimately emerge from, and revert to, a mode of meditative experience. In the words of Edward Conze, "meditational practices constitute the very core of the Buddhist approach to life... As prayer in Christianity, so meditation is here the very heartbeat of the religion" (Conze 1956: 11).

Approached through this "hermeneutic of experience," the interminable conceptual categories expounded in scholastic Buddhist path treatises, or the hair-splitting classifications of the Abhidharmikas, are frequently presumed to be grounded in a nonconceptual mode (or modes) of cognition. Buddhist philosophy, we are told, clearly articulates the difference between the "roots" and the "branches," the "fundamental" and the "traces," the "absolute" and the "contingent." Indeed, the Buddhist tradition is itself often designated an "expedient means" (upāya) in order to differentiate it from the fundamental truth of emptiness (śünyatā) which transcends sectarian or institutional allegiances. To quote again from Conze, "each and every [Buddhist philosophical] proposition must be considered in reference to its spiritual intention and 
as a formulation of meditational experiences acquired in the course of the process of winning salvation.",

Buddhist philosophical literature is thus presumed to constitute, among other things, a detailed map of inner space, charted with the aid of sophisticated meditation techniques that allow Buddhist yogis to travel the breadth of the psychic terrain. Accordingly, many of the key technical terms relating to Buddhist praxis, including samatha (concentration), vipaśyanä (insight), samādhi (trance), samäpatti (higher attainment), prajña (wisdom), smrti (mindfulness), srotaāpatti (stream-entry), ${ }^{2}$ kenshō (seeing one's nature), satori (understanding), and even makyō (realm of illusion), are interpreted phenomenologically: they are assumed to designate discrete "states of consciousness" experienced by Buddhist practitioners in the midst of their meditative practice.

Scholarly writings on mysticism continue to be preoccupied with the epistemological problems entailed in the notion of direct or unmediated experience. Ninian Smart, Steven Katz, Robert Forman, and numerous others have carried on a lively debate over the degree to which mystical experiences are shaped by prior culturally mediated expectations and presuppositions, over whether or not one can separate a mystic's report of his experiences from his interpretations, over the existence of so-called pure consciousness devoid of intentional objects, over competing schemes for typologizing mystical states, and so on. ${ }^{3} \mathrm{I}$ do not intend to enlist in this debate here. ${ }^{4}$ Rather, I would draw attention to a presupposition made by virtually all parties to these debates, namely, that terms such as "religious experience," "mystical experience," and/or "meditative experience" are primarily referential or denotative, i.e., that their signification lies in the signifieds to which they allegedly refer.

This is clearly an important issue for scholars of Buddhism, who tend to accept the view that meditative experience was central to the Buddhist iradition throughout its history. There are, in fact, cogent grounds on which to question this supposition. As mentioned above, Wayne Proudfoot has argued that the rhetoric of religious experience in the West is of recent vintage, and the popularity of the "hermeneutic of experience" is due in part to the manner in which it seemed to offer a defense against secular critique. Wilhelm 
Halbfass has made a similar point with reference to the writings of contemporary Hindu and Neo-Vedānta exegetes such as Sarvepalli Radhakrishnan (1888-1975), whose overriding emphasis on experience is largely apologetic, reflecting "the encounter of the Indian tradition with Western science and philosophy" (Halbfass 1988: 395). Finally, the epistemic commitments attendant upon the rhetoric of experience in the discipline of religious studies are patently Cartesian, and we should exercise caution when imposing a seventeenth-century European metaphysic on medieval Buddhist writings.

Buddhist scriptural materials present daunting philological and hermeneutic difficulties to the contemporary exegete. The tendency to approach the compendious Buddhist mārga treatises (texts delineating the stages on the Buddhist path) as if they presented a phenomenological analysis of the experiences of seasoned meditators is understandable: how else are we to approach such materials? Nevertheless, I hope to show that the "phenomenological approach" may well be misguided; in the end it may reveal more about the dangers of projection and transference in the study of Buddhism than it tells us about Buddhism itself. ${ }^{5}$ For there is evidence that the emphasis on "transformative personal experience" may not have been as central to traditional Buddhist monastic practice as some modern exegetes would have us believe. Moreover, those contemporary Buddhist movements that do emphasize meditative experience often turn out to be movements that were themselves influenced by their encounter with the Occident.

It is, of course, impossible to do justice to the issue in a single article; the so-called Buddhist tradition is far from a univocal entity, and a convincing revisionist analysis of a second-century Indian scholastic text may tell us little about a seventh-century Chinese Tantric liturgy, or the poetry of a thirteenth-century Japanese Zen abbot. But while few would contest the diversity of phenomena that go under the name "Buddhist," many still approach such disparate materials with a set of broad assumptions concerning the nature and goals of Buddhist practice.

The assumptions that inform scholarly readings of classical Buddhist materials are shaped in part by our familiarity with the living 
Buddhist tradition, and when it comes to meditation two contemporary traditions have dominated Western discussions of Buddhist meditation: the vipassana movement in Southeast Asia and Japaneze Zen. Indeed, the impact of these two forms of practice on Buddhist scholarship is far out of proportion to their size or influence in their homelands. The reason for their stature in the West is no mystery: partisans of both vipassana and Zen have been largely responsible for perpetuating the image of Buddhism as a rational, humanistic, contemplative creed that eschews magic and empty ritual. And it was this image of an enlightened spirituality based on experience rather than faith that attracted many scholars to Buddhism in the first place.

In this article I will argue the need to reexamine the conceptual categories and epistemological assumptions that inform many modern presentations of Buddhism. Specifically, I will show that the emphasis on meditative experience as the sine qua non of Buddhism is misplaced, and that even in the case of contemporary vipassana and Zen, historical, ethnographic, and philosophical analysis belies the notion that the rhetoric of experience functions ostensively to refer to discrete, identifiable, and replicable "states of consciousness." This is not to deny that veteran Buddhist meditators have "experiences," just that the relationship between what they "experience" and what they say about it is far more tenuous than is sometimes believed.

\section{Zen and the Art of Participant-Observation}

In his short classic Zen in the Art of Archery, Eugen Herrigel, following the lead of D.T. Suzuki, assures us that Zen "is not speculation at all but immediate experience of what, as the bottomless ground of Being, cannot be apprehended by intellectual means, and cannot be conceived or interpreted even after the most unequivocal and incontestable experiences: one knows it by not knowing it" (Herrigel 1971: 7; my emphasis). Putting aside the obscurantism of this passage, one does gather that the goal of Zen is some sort of personal experience-an experience that Herrigel sought through training in Zen archery. After a long and somewhat frustrating apprenticeship, in which he learns not to shoot the arrow but rather 
to allow the arrow to "shoot itself," Herrigel finally has his first breakthrough. Herrigel's dramatic account of this moment reads as follows:

\begin{abstract}
Weeks went by without my advancing a step. At the same time I discovered that this did not disturb me in the least. Had I grown tired of the whole business? Whether I learned the art or not, whether I experienced what the Master meant by "It" or not, whether I found the way to Zen or not-all this suddenly seemed to have become so remote, so indifferent, that it no longer troubled me.... Then, one day, after a shot, the Master made a deep bow and broke off the lesson. "Just then 'It' shot!' he cried, as I stared at him bewildered. And when I at last understood what he meant I couldn't suppress a sudden woop of delight. "What I have said," the Master told me severely, "was not praise, only a statement that ought not to touch you. Nor was my bow meant for you, for you are entirely innocent of this shot. You remained this time absolutely self-oblivious and without purpose in the highest tension, so that the shot fell from you like a ripe fruit. Now go on practicing as if nothing had happened." (Herrigel 1971: 56-61)
\end{abstract}

There are, of course, good reasons to question the veracity of this curious document. While Herrigel presents us with a first-person narrative, placing dialogue in quotation marks, we must remember that his archery teacher spoke only Japanese, and that Herrigel required the aid of an interpreter throughout the course of his training. Moreover, instructions were given while Herrigel was occupied with his bow, so he could hardly have taken verbatim notes. The book is clearly less a record of what the master actually said, than a record of what Herrigel thought the master meant.

Even if we are sympathetic to Herrigel's version of the episode, we are still struck by the fact that Herrigel's description of his accomplishment belies his own understanding of the aims of Zen archery. Both the introduction to the book by D.T. Suzuki and earlier comments by Herrigel assure the reader that the goal of such training is some sort of "incontestable experience" in which the student becomes one with the "groundlessness" of being (Herrigel 1971: 7). Yet Herrigel only learns of his success when informed of it by a third party. Herrigel's knowledge that "It" released the arrow came not through some powerful personal experiencemystical, pure, non-dual, or otherwise-but rather secondhand, through the word of his teacher.

One might question the wisdom of beginning my inquiry with Herrigel's somewhat idiosyncratic work. Despite the imprimatur of 
D.T. Suzuki's introduction, Herrigel was neither a Buddhist scholar, nor an initiate in a traditional Buddhist sect. He was, rather, a German academic with a distinctly romantic bent of mind, who taught philosophy at Tokyo University in the 1920s. ${ }^{6}$ Moreover, Herrigel had little formal training in Buddhist thought and history, and a scant command of the Japanese language. Be that as it may, Zen in the Art of Archery is useful for us as it illustrates many of the shortcomings characteristic of writings on "Buddhist mysticism," including (1) the poor quality by anthropological standards of many "field reports" in this area-little consideration, if any, is paid to the rudiments of "participant-observer" protocol, and virtually no attempt is made to distinguish between emic and etic description, or to separate primary ethnographic data from secondary interpretation; (2) the unabashed romanticism, replete with notions of the "mysterious East" that infect such narratives; (3) the uncritical assumption that, since the essential "experience" underlying the outer culturally mediated forms remains unchanged through time and across cultures, contemporary practices can be used as transparent windows to the past, and the corollary notion that a "living master" is preferable to a "dead text;" and last but not least, (4) the tendency to psychologize ritual acts-to assume that the cultural significance and religious intent of a particular practice is best located in the subjective experience it is intended to induce, rather than in a mode of behavior perfected through rehearsal and repetition. (Note that the final stage in Herrigel's training involved a public performance and examination of his archery skills. This task required that the execution of the rite become so routinized that the added pressures of a public venue would have no effect upon his performance [Herrigel 1971: 71-72].)

\section{Experience, Scripture, and Exegetical Authority}

First-person accounts of Buddhist mystical experiences are, in fact, not as common as one might expect in a tradition supposedly intent on producing them, and of the few premodern autobiographical accounts we do possess, most are explicitly "Tantric" in nature, rendering them of somewhat limited use in an analysis of "mainstream" Buddhist meditation theory. The 
orthodox explanation for the paucity of personal testimonials is that Buddhist monks were explicitly forbidden from vaunting their spiritual accomplishments in public. ${ }^{7}$ There is little doubt that such a prohibition would have discouraged the writing of personal accounts describing one's meditative experience. However, this prohibition would have served a tactical purpose as well, as it allowed the tradition to tacitly impute meditative accomplishment to eminent monks, while at the same time obviating the need for such monks to make any explicit claims on their own behalf. ${ }^{8}$

In any event, while personal accounts may be lacking, there is no shortage of prescriptive manuals delineating in exhaustive detail the stages of the Buddhist path (märga). These texts were highly esteemed in the monastic tradition: Buddhaghosa's Visuddhimagga ("Path of Purity"), for example, constituted the central authority on all issues pertaining to the Buddhist path for Theravāda Buddhists. Chih-i's Mo-ho chih-kuan ("The Great Calming and Contemplation") was accorded an analogous position in the Chinese T'ien-t'ai tradition, while Indian and Tibetan monastics turned to works such as Asanga's Bodhisattvabhumi ("Stages of the Bodhisattva's Path"), Kamalaśîla's Bhāvanākrama ("Course of Practice"), Tsong kha pa's Lam rim chen mo ("Great Book on the Stages of the Path"), or the Abhisamayalamkāra ("Ornament of Realizations") attributed to Maitreyanātha. These massive exegetical works were often accorded an authority that was, for all practical purposes, equal to that of the sermons of the Buddha.

There is a marked tendency in the field to assume that such mārga treatises are descriptive accounts of meditative states based on the personal experiences of accomplished adepts, rather than prescriptive systematizations of scriptural materials. Paul Griffiths, for example, in his study of Indian Buddhist meditation theory, asserts that, "The scholastic texts of Indian Buddhism preserve for us an especially highly developed and tightly structured set of descriptions of virtuoso religious practice; they are therefore significant for our understanding of such practice considered as an important aspect of the history of religions" (Griffiths 1983a: 2-3). And in a detailed philosophical analysis of the concept of nirodhasamäpatti, Griffiths begins with the following: "It is upon meditative practice that the religious life of the Buddhist virtuoso is based and from 
such practice that systematic Buddhist philosophical and soteriological theory begins.... It would hardly be an exaggeration to say that the whole of the magnificently complex edifice of Buddhist philosophy is a drawing out and systematization of the implications of [meditative] experience" (Griffiths 1986: xiii).

Griffiths, who is interested in the role that meditative states play in Buddhist philosophy, works with a set of highly abstruse and quintessentially scholastic texts. Yet he never directly addresses the issue as to whether or not the authors of such texts were themselves the religious virtuosos to whom he refers. This begs the issue, especially as the notion of nirodha has all the makings of a wholly scholastic construct. (Note that nirodha is characterized as the utter cessation of physical and mental processes-a state that would be indistinguishable from death were it not for the fact that the body, which is rendered temporarily impregnable, retains its "vitality" [āyus $]$ and inner heat. A first-person description of such a state is a logical impossibility. $)^{9}$

Unlike Griffiths, who, like many of his professional colleagues, assumes that Indian Buddhist philosophical systems emerged in part from reflection on the meditative experiences of accomplished monks, Lambert Schmithausen tries to prove it. In a short but provocative article, Schmithausen argues that the idealist philosophy of the Yogācāra school must have arisen in conjunction with a particular type of meditative experience: "Yogācāra idealism primarily resulted from a generalization of a fact observed in the case of meditation-objects, i.e., in the context of spiritual practice", (Schmithausen 1976: 241, emphasis in original). This is not to say that this doctrine emerged in a philosophical vacuum: "Specifically idealist formulations defining all phenomena as being nothing but mind (cittamātra) or cognition (vijñaptimātra) obviously made their first appearance in connection with reflections on objects of visionary meditation. Their generalization, however, was essentially motivated or made possible by the historical background of Mahāyānistic illusionism describing all finite entities or notions as empty, unreal, and illusory, comparable to magic or to a dream, etc." (ibid.: 249).

It would take us too far afield to examine the details of Schmithausen's historical reconstruction here. Suffice it to say that 
nowhere does Schmithausen claim access to the meditative states that, according to his argument, constitute the provenance of Yogācāra idealism. His own argument does not demonstrate that Yogācāra idealism emerged from reflection on an actual experience, so much as it shows that such a position can be derived from reflection upon the prescriptive meditative and soteriological ideals enunciated in Mahāyāna textual sources. There is simply no need to trace the emergence of Buddhist idealism to experiences attained in meditative trance; idealist positions can be derived from philosophical inquiry into the status of perceptions arising due to simple epistemic error (the rope-snake analogy comes to mind), or from reflection on the ontology of dreams (as is found in the Taoist Chuangtzu). ${ }^{10}$

In fact, the Buddhist tradition is itself hesitant to claim that mārga narratives were composed on the basis of personal experience. This is not to suggest that the authors did not themselves engage in meditative practices. (Indeed, Buddhist hagiographical sources often depict these monks as accomplished yogis and powerful thaumaturges.) My point is rather that the major Buddhist path treatises do not include personal testimonials by their authors attesting to the veracity of the meditative states they describe. On the contrary, the authors seem to have gone to great lengths to efface their own voices; these accounts are, for the most part, eminently impersonal, relying exclusively on scriptural proof-texts to substantiate their exegeses. In fact it is difficult to imagine how anyone could mistake this genre of religious literature for "expressions" or "reports" of personal experiences; they are first and foremost scholastic compendiums, compiled by monks of formidable learning who were attempting to systematize and schematize the confused and often conflicting descriptions of practices and stages found scattered throughout the canon. ${ }^{11}$ Moreover, they are filled with detailed accounts of the supernatural attainments (siddhi) that accompany particular meditative trances, including such powers as walking through walls, flying through the air, becoming invisible, reading minds, recalling past lives, and so on. ${ }^{12}$

To reiterate, it is not merely that we can never know whether or not the seminal Buddhist märga texts were informed by the spiritual 
experiences of their authors. Rather, the legitimacy of these texts would have been impugned had their authors openly relied upon, or even alluded to, their own experiences. Buddhist philosophers, including such authorities as Dharmakīrti and Candrakīrti, were generally circumspect regarding truth claims based on appeals to personal experience, yogic or otherwise. ${ }^{13}$ The legitimacy and authority of Buddhist mārga narratives lie precisely in their filiality to the canon; much of these texts often consists of little more than carefully organized excerpts from sūtras and commentaries. While their authors need not have been accomplished yogis, an impeccable knowledge of the Buddhist scriptural legacy was clearly de rigueur.

A paradigmatic example is the Visuddhimagga, a work accepted throughout the Theravāda world as the unimpeachable authority on everything related to meditation. The author, Buddhaghosa, was a fifth-century Indian monk who traveled to Sri Lanka and established himself at the great monastery Anurādhapura, where he is said to have spent his time mastering the Sinhalese commentarial tradition under Sanghapāla. He then devoted himself to translating Sinhalese works into Pāli, and composing his own commentaries and treatises. Nowhere in Buddhaghosa's works does he claim to have relied upon personal inspiration or meditative insight. The situation is, in fact, quite to the contrary: by his own account the Visuddhimagga was composed on the basis of his study of the available scriptural and commentarial corpus: "I shall expound the comforting Path of Purification, pure in expositions, relying on the teaching of the dwellers in the Great Monastery [Anurādhapura]..." Indeed, only once in the Visuddhimagga does Buddhaghosa openly advance an opinion of his own, which consists solely in expressing his preference for one scriptural interpretation over another with regard to a particularly arcane point concerning the recollection of past lives. ${ }^{14}$

Precisely the same is true of Chih-i's (538-597) classic, the Mo-ho chih-kua' . Not once does the author of this massive authoritative compendium on Buddhist practice explicitly refer to his own meditative experience. ${ }^{15}$ In fact, the same may be said for virtually all of the major Buddhist mārga treatises delineating the "stages of the path;"' it would be difficult, if not impossible, to construe these 
scholastic edifices as predicated upon the meditative accomplishments of their authors.

One might ask if it is really plausible that the vast Buddhist corpus bearing on the subject of meditation and meditative states, and the highly specialized language that evolved in conjunction with the discussion and differentiation of such states, could have emerged in the absence of any real experiential referent(s). In response, I would draw attention to the enormous body of academic literature bearing on mysticism in the West, growing out of the pioneering work of Rudolf Otto, William James, William Ernest Hocking, W.T. Stace, and so on. Few of the major theologians and academics who have contributed to this literature claim to have cxperienced the states they attempt to describe and analyze. One of the most influential theorists in the field, William James, openly admits to having no propensity for mysticism: "Whether my treatment of mystical states will shed more light or darkness, I do not know, for my own constitution shuts me out from their enjoyment almost entirely, and I can speak of them only at second hand"' (James 1961: 299). Yet the apparent paucity (if not absence) of first-hand experience does not seem to have impeded the evolution of a descriptive, typological, and theoretical discourse on "mystical experience" in Western academe. ${ }^{16}$

\section{Experience and Monastic Praxis}

I do not want to suggest that all scholars have uncritically accepted Buddhist mārga treatises as descriptive mystical accounts. Robert Buswell and Robert Gimello, the editors of a recent publication on Buddhist märga theory, are sensitive to the patently prescriptive nature of this genre:

The various stages outlined in highly schematized versions of mārga may have no direct connection with any real problems or experiences in the lives of real persons. They may apply only analogically and normatively, prompting students to mold their own life experiences according to the ideals of their religious heritage. Or they may be means by which individual experience can be made communal, to the extent that common prescriptions of practice may foster experiences similar to those of one's colleagues. (Buswell and Gimello eds. 1992: 11)

While rejecting the notion that Buddhist märga texts were written as first-hand reports, Buswell and Gimello suggest nevertheless that 
such texts were used to "foster" certain meditative experiences in Buddhist practitioners. Thus the prescriptive model presented in the commentarial literature is rendered descriptive of the inner experience of one who rigorously strives to implement it. This position is fully elaborated in Robert Gimello's seminal essay on Buddhism and mystical experience, in which he argues that Buddhist practices were designed so as to evoke experiences that conform to, and thus confirm, the central tenets of Buddhism: "rather than speak of Buddhist doctrines as interpretations of Buddhist mystical experiences, one might better speak of Buddhist mystical experiences as deliberately contrived exemplifications of Buddhist doctrine" (Gimello 1978: 193).

In so far as such treatises were used as "guidebooks" for meditative practice, Gimello's analysis appears sound. Yet Gimello's theoretical remarks assume, rather than demonstrate, that Buddhist mārga texts were actually used in such a manner. This is an area in which philosophical reflection must take a back seat to historical and ethnographic research. A summary perusal of the available historical and ethnographic literature suggests that Buddhist märga texts were manipulated much as were Buddhist sūtras; that is, they functioned more as sacred talismans than as practical guides. Texts on meditation were venerated as invaluable spiritual treasures to be copied, memorized, chanted, and otherwise revered. ${ }^{17}$

In fact, contrary to the image propagated by twentieth-century apologists, the actual practice of what we would call meditation rarely played a major role in Buddhist monastic life. The ubiquitous notion of mappo or the "final degenerate age of the dharma" served to reinforce the notion that "enlightenment" was not in fact a viable goal for monks living in inauspicious times. This is readily confirmed by anthropological accounts: modern monks, at least those who are not associated with "Protestant Buddhist" revival movements (see below), consider nirvāna to be an impossibly distant ideal. ${ }^{18}$ As such, the more earnest monks are content to spend their time cultivating moral virtue, studying scriptures, and performing merit-making rituals in the hope of being reborn in more favorable circumstances.

We will see below that the two Buddhist traditions most com- 
monly associated with meditation-Theravāda vipassanā and Japanese Zen-were both influenced by recent reform movements that stressed the centrality of meditation to the Buddhist path. The practice of what is now known as vipassana can be traced to early twentieth-century teachers such as Phra Acharn Mun (1870-1949) in Thailand, Dharmapāla (1864-1933) in Sri Lanka, and U Nārada (1868-1955) and Ledi Sayādaw (1846-1923) in Burma. Prior to this time, bhāvanā (meditation, or mental development) consisted largely of the recitation of Pâli texts pertaining to meditation (such as the Satipatthāna-sutta and the Mettā-sutta), chanting verses enumerating the qualities of the Buddha, reciting formulaic lists of the thirty-two parts of the body, and so on. Such exercises are closer to what we might call devotional practices than to meditation, in that they are intended as vehicles for accumulating merit and cultivating wholesome attitudes, rather than as devices for inducing "altered states of consciousness."

Even today, after the full effect of the vipassana movement has been felt, historical and ethnographic studies still testify to the fact that meditation plays a minor if not negligible role in the lives of the majority of Theravāda monks. ${ }^{19}$ In fact, most such studies have little if anything to say about the role of meditation in monastic training, with the notable exception of a few monographs specifically devoted to contemporary Theravāda reform movements. ${ }^{20}$ While such reforms do promote meditation as a central component of the path, their effect has been felt more in the realm of ideology than in the realm of praxis; the vast majority of Theravāda monks still consider their vocation to lie in ganthadhura or "teaching," rather than vipassanädhura or "'meditation.", Moreover, even the vipassanädhura monks will insist that the development of morality (sila) through proper observance of the monastic rule (vinaya) is more essential to the path than meditation per se. ${ }^{22}$ Carrithers points out that the stress on moral behavior and the relative lack of any emphasis on religious experience is in fact fully consonant with the thrust of Theravāda tradition-a tradition that "considers spectacular experience as an obstacle to practice, because of the great emotional disturbance involved.... There is a profound unity in Buddhism over this question, for the objective of meditation in all Buddhist traditions is the cultivation of wisdom 
founded in tranquility and equanimity" (Carrithers 1983: 19). While we do find some contemporary Theravāda teachers touting the benefits of exalted meditative experience, they are invariably associated with modern reform movements stimulated by contact with Western missionaries and Occidental scholarship. We will return to this point below.

The same is largely true of Japanese Zen, the "meditation school" of East Asian Buddhism. The word "Zen' commonly conjures up images of austere black-robed monks wholly intent upon reaching "'enlightenment" (satori) through the practice of introspective meditation under a strict master. But such an image is in part the product of twentieth-century Japanese intellectuals who appropriated exegetical strategies borrowed from the West in their effort to rationalize Japanese Buddhism. Japanese Zen apologists, conversant in contemporary Western philosophy, emphasized the role of religious experience in order to counter the threat posed to Buddhism by modernization, secularization, and science (see below). In point of fact, traditional Ch' an and Zen practice was oriented not towards engendering "enlightenment", experiences, but rather to perfecting the ritual performance of Buddhahood (Sharf 1989). The modern notion that Ch'an and Zen monks were required to experience satori before they could "inherit the dharma" is simply inaccurate. ${ }^{23}$

Even in the modern period one rarely hears mention of kenshō or satori in traditional Rinzai and Sōtō monks halls $(s \bar{d} d \bar{o})$. Novice monks (unsui) studying in Zen monasteries are typically anxious to leave the training hall as soon as possible, hurrying home to take charge of the family temple after completing their minimum one-tothree years in training. The few ambitious monks who possess the talent and drive to become "masters" (rōshi) will remain in the monastery for upwards of ten to fifteen years, busily engaged in perfecting the elaborate ceremonial repertoire incumbent upon a Zen rōshi. In the case of Rinzai Zen, this repertoire includes mastering vast selections from Zen kōan collections and commentaries so as to be able to guide students through ritualized kōan exchanges. Here too, prescriptive religious texts are treated not so much as practical guides for meditation, but rather as liturgies to be memorized for ritual performance. 
The picture of Korean Sŏn Buddhist monastic life that emerges from Robert Buswell's recent book (1992) resembles the pattern seen above. While it is true that the monks and nuns practicing in Sŏn meditation halls are held in high esteem, such persons constitute no more than about five percent of the ordained clergy in the dominant Chogye order (Buswell 1992: 167). As for the remaining ninety-five percent, "the majority ... spend no time in meditation, and many have no intention of ever undertaking such training", (ibid.: 218). Moreover, while the Korean Sŏn tradition pays lipservice to "sudden enlightenment," Buswell notes that "a disciplined life, not the transformative experience of enlightenment, is actually most crucial to the religion. This need not necessarily be even an examined, or an informed, life, though those would be highly prized, but one that is so closely and carefully structured as to provide little opportunity for ethical failings or mental defilements to manifest themselves" (ibid.: 219).

Finally, I should briefly mention Buddhist Tantra, a late Buddhist development that traditionally placed more emphasis on spiritual praxis than doctrinal learning. Scholars of Tantra (who tend to be trained in philology and doctrinal history rather than in the social sciences), often depict Tantric adepts as capable of astounding mental feats made possible through meditative endeavor. Such monks, we are told, are able to mentally construct alternative universes of mind-boggling complexity. Following the detailed instructions found in Tantric ritual manuals, Tantric monks are said to visualize hundreds and even thousands of technicolor deities, all of which can be simultaneously held in the "mind's eye" for extended periods of time. Moreover, the climactic ritual procedures that signify the identity of practitioner and deity are regarded by scholars as the outward manifestation of an inward mystical union.

In fact, much of the scholarship in this area suffers from the alltoo-common methodological error mentioned above: scholars read ideological prescription as phenomenological description. As soon as one redirects attention away from the content of the manuals, towards the manner in which such texts are actually used, one finds that the elaborate "visualizations" or "contemplations" recorded in the manuals are instantiated through formal recitation and ritual 
gesture. Very little time, if any, is allotted for assimilating the content of the texts, or for fixing an image of a deity in the mind. Instead, monks chant the texts in unison, hurrying through each section of the ritual in order to finish it in the time allotted. This is true not only in the case of Japanese Tantra (i.e., the Shingon and Tendai mikkyo lineages), which I know from my own field research (see Sharf 1994), but also in the case of the Tibetan tradition. Stephan Beyer, while accepting the notion that Tantric rites are "meditations," is nevertheless candid about the problems involved:

The ability to achieve single-minded concentration on a vividly appearing picture is the result of long and really rather frustrating practice. We must remember-and this point should be emphasized - that the visualization is performed during a ritual; that is, the practitioner is reciting a text (which is either placed on a small table in front of him or which he has memorized), and the visualization takes place in time with the rhythmically chanted textual description of the evocation.... The reading of the ritual text in the assembly hall often goes at breakneck speed, and the vast majority of monks are unable to visualize that quickly, if indeed they are able to visualize at all. (Beyer 1973: 71)

Beyer goes on to suggest that success in visualization is a rare occurrence: "I once asked a highly placed incarnate lama if he could really visualize the subtle deities. He replied that, roughly and in a general way, he could; but he added that the Toden rinpoch'e (the head of all the yogins), with more than fifty years of practice in visualization, could picture these deities in perfect detail and keep track of them all at once" (ibid.: 75). I also took the liberty of questioning a number of Tantric teachers, including Japanese ajari (empowered masters) and a well-known Tibetan tulku in a Kagyüpa lineage, about their own meditative accomplishments. All reported rather limited success at visualization, but they were usually quick to explain that their own teacher, or the head of their lineage, or the founder of their sect, or some great yogi of old did in fact succeed in mentally constructing alternative realities. It would seem that contemporary scholars are not the only ones predisposed to ignore the disjunction between the textual ideal on the one hand, and the lived contingencies of religious practice on the other.

I do not want to suggest that lucid visualization of this sort is 
impossible in principle-there may indeed be Tantric yogis who, practicing in quiet isolation, are able to create an eidetic internal vision of a complex mandala. However, this is not of particular relevance to an understanding of Tantric rituals as performed by the vast majority of Asian practitioners, who simply do not aspire to such psychic feats. Ethnographic accounts strongly suggest that such practitioners are more concerned with ceremony and performance than with "inner experience" per se.

\section{The Invention of Tradition}

At this point some may be tempted to invoke the time-worn distinction between "elite" and "popular" traditions. Surely, the fact that most Buddhists practice meditation in a "routinized" and perhaps even "superficial" manner does not mean that all Buddhists do so. Surely, there must have been some who have diligently and energetically followed the prescribed techniques and have thereby come to experience the exalted states promised in the märga texts. Surely, the fact that only a handful of Buddhists ever succeed in no way detracts from the pivotal role played by the ideal of meditative experience in the Buddhist tradition.

Such an objection tacitly accepts the notion that meditative experience has in fact been the ideal to which Buddhists aspired throughout Asian history. One often hears scholars describe contemporary monastic practices under the rubric of "routinization" or "banalization," implying the degeneration of an earlier and supposedly purer practice in which "outward form" was subordinated to "inner experience." (Note that this interpretative strategy recapitulates classical Buddhist mappo theory.) Yet there is evidence that the Buddhist emphasis on "inner experience" is in large part a product of modern and often lay-oriented reform movements, most notably those associated with the vipassana revival in Southeast Asia, and those associated with contemporary Zen movements in Japan.

As I have discussed the modern construction of "Zen spirituality" elsewhere, I will present only the briefest summary of my findings here. ${ }^{24}$ Western conceptions of Zen have been unduly influenced by the writings of a small group of twentieth-century 
Japanese intellectuals, many of whom are associated with the socalled Kyoto School (Kyōto gakuha), including D.T. Suzuki (18701966), Hisamatsu Shin'ichi (1889-1980), and Nishitani Keiji (1900-1990). The view of Zen propounded by these men was based not so much on their familiarity with classical Zen monasticism, as on a particular ideological agenda inherited from the New Buddhism (shin bukkyō) of the Meiji period (1868-1912).

New Buddhism developed in response to the devastating critique and persecution of Buddhism (haibutsu kishaku) initiated by the government in the early years of the Meiji. Government propagandists, who sought to turn Shinto into a tool of state ideology, condemned Buddhism as a corrupt, decadent, anti-social, parasitic, and superstitious creed inimical to Japan's need for scientific and technological advancement. Buddhist reformers responded by aknowledging the corruption and self-interest that characterized the late Tokugawa Buddhist establishment, but they insisted that such corruption merely indicated the degree to which Buddhism had fallen from its spiritual roots. Accordingly, the problem lay not in Buddhism itself, but rather in the institutional and sectarian trappings to which Buddhism had fallen prey.

In this defensive strategy one can discern the influence of the late nineteenth-century European Zeitgeist that permeated university campuses in Meiji Japan. Japanese intellectuals, seeking to bring their nation into the "modern world," were naturally drawn to the European critique of institutional religion-the legacy of the anticlericism and anti-ritualism of the Reformation, the rationalism and empiricism of the Enlightenment, the romanticism of figures such as Schleiermacher and Dilthey, and the existentialism of Nietzsche. Some Japanese Buddhist leaders went so far as to argue that the official suppression of Buddhism was in fact a purifying force, which would purge Buddhism of its degenerate accretions and effect a return to the original "essence" of the Buddha's teachings. The result, which came to be known as New Buddhism, was touted as "modern," "cosmopolitan," "humanistic," and "socially responsible." This reconstructed Buddhism, under the guise of "true" or "pure" Buddhism, was conceived of as a "world religion" ready to take its rightful place alongside other universal creeds. 
Proponents of Zen Buddhism followed suit, arguing that Zen is immune to Enlightenment critiques of religion precisely because it is not a religion in the institutional sense at all; it is, rather, an uncompromisingly empirical, rational, and scientific mode of inquiry into the true nature of things. The early works of D.T. Suzuki, who had studied in his youth under the German-American essayist and proponent of the "Religion of Science" Paul Carus, are written very much in the spirit of New Buddhism. In an English introduction to Buddhism first published in 1907, for example, Suzuki confidently declares that Mahāyāna is both rational and empirical, and that it "anticipated the outcome of modern psychological researches" (1963: 40). But Suzuki's approach to Buddhist exegesis was to shift dramatically following the 1911 publication of Zen no kenkyu (An Inquiry into the Good) by Suzuki's longtime friend, the philosopher Nishida Kitarō (1870-1945).

Nishida's essay revolved around the elucidation of "pure experience" (junsui keiken). Pure experience, according to Nishida, means to "know reality exactly as it is ... without the admixture of any thinking or discrimination.... [P] ure experience is identical with immediate experience. When one immediately experiences a conscious state of the self, there is still neither subject nor object; knowledge and its object are entirely one. This is the purest form of experience. ${ }^{25}$ Nishida's emphasis on pure experience was based on his somewhat idiosyncratic reading of Western philosophy, particularly the writings of William James, to which he was introduced by none other than D.T. Suzuki. Suzuki was quick to appreciate the significance of Nishida's pure experience, making it the central hermeneutical principle in his presentations of Zen. Suzuki began to render any and all Zen cultural artifacts-from kōan exchanges to dry-landscape gardens-as "expressions of" or "pointers toward" a pure, unmediated, and non-dual experience, known in Zen as satori. Not only was such an experience touted as the essence of Zen, it was also said to lie at the heart of all authentic religious teachings, be they Christian, Islamic, Hindu, or whatever. ${ }^{26}$ This approach to Zen exegesis has since been adopted by a number of Japanese intellectuals, including two who have been particularly active in Buddhist-Christian dialogue: Nishitani Keiji and Abe Masao. 
The irony of this situation is that the key Japanese terms for "experience" - keiken and taiken-are rarely attested in premodern Japanese texts. Their contemporary currency dates to the early Meiji, when they were adopted to render Western philosophical terms for which there was no ready Japanese equivalent. One searches in vain for a premodern Chinese or Japanese equivalent to the phenomenological notion of experience. Nor is it legitimate to interpret such technical Zen terms as satori (literally, to understand), or kenshō (to see one's original nature), as denoting some species of "unmediated experience" in the sense of Nishida's junsui keiken. In traditional Chinese Buddhist literature, such terms are used to denote the full comprehension and appreciation of central Buddhist tenets such as emptiness, Buddha-nature, or dependent origination. There are simply no a priori grounds for conceiving such moments of insight in phenomenological terms. Indeed, Chinese Buddhist commentators in general, and Ch'an exegetes in particular, tend to be antipathetic to any form of phenomenological reduction.

While the writings of D.T. Suzuki and his followers profoundly influenced popular conceptions of Zen both in Japan and in the West, their influence inside traditional Rinzai and Sōtō training halls has been rather limited. "Professional" Zen monks typically have little regard for university professors and intellectuals who, lacking the appropriate ritual training and institutional credentials (i.e., “dharma transmission'), nonetheless feel free to pontificate on the "essence" of Zen. As I have argued above, Zen monastic training in contemporary Japan continues to emphasize physical discipline and ritual competence, while little if any attention is paid to inner experience. The notable exceptions to this rule are two contemporary lay-oriented organizations, the F.A.S. Society and the Sanbōkyōdan, on which I will comment only briefly.

The F.A.S. Society was founded by the philosopher and lay Zen practitioner Hisamatsu Shin'ichi in 1958 after he returned from extensive travels abroad. ${ }^{27}$ Hisamatsu, following Nishida and Suzuki, insisted that true Zen is not religion per se, but rather the non-contingent, trans-cultural, non-dual spiritual gnosis that underlies all authentic religious inspiration. While the F.A.S. continues to hold weekly study meetings and occasional Zen retreats in 
Kyoto, members of this loose-knit organization have never been great in number, and their influence is felt primarily through the writings of Hisamatsu and a few of his followers (notably Abe Masao). ${ }^{28}$

Unlike the F.A.S. the Sanbōkyōdan (Three Treasures Association) has had a major impact on Western conceptions of Zen practice. This sect was formally established by Yasutani Hakuun (18851973) in 1954, although Yasutani had in fact been disseminating the teachings of his own innovative teacher Harada Daiun (18701961) since the 1940s. The Sanbōkyōdan, which has declared its legal and ideological independence from the Zen establishment, has popularized a form of intensive meditation practice oriented specifically toward lay practitioners. Teachers in the HaradaYasutani line emphasize a rather idiosyncratic use of kōan, coupled with the controversial practice of placing students under intense pressure to quickly experience satori.

This modern Zen movement constitutes a fascinating synthesis of the anti-establishment and anti-clerical ideology of Meiji New Buddhism, coupled with an emphasis on meditative experience and satori popularized by Suzuki. Moreover, it has all the makings of a Japanese "new religion"' (shin shükyō), with its disdain for scriptural study, its shrill polemics against the orthodox Zen establishment, its organized use of written testimonials in efforts at proselytization, and its promise of rapid spiritual progress (the "democratization" of satori). ${ }^{29}$ Indeed, such rapid progress is possible precisely because accomplishment in Zen is no longer seen in terms of doctrinal or ritual mastery. Rather, spiritual success lies in the momentary experience of satori-a state that students in the Sanbōkyōdan have been known to experience in their very first seven-day intensive retreat (sesshin). It is significant that many of the key personalities responsible for introducing Zen to the West have been affiliated with this controversial and relatively marginal Japanese religious movement. ${ }^{30}$

The laicized styles of Zen discussed above might be called, to borrow a notion from Obeyesekere, "Protestant Zen" in so far as they strive to rationalize Zen practice through minimizing the importance of the pietistic, ritualistic, and sacramental dimensions of practice in favor of an instrumental or goal-directed approach. ${ }^{31}$ 
At the same time, they actively mystify the goal, now conceived in terms of transcendent wisdom and ineffable meditative experience. Proponents of Protestant Zen are often antagonistic to the orthodox Rinzai and Sōtō institutions, proclaiming that traditional Zen is moribund and the priesthood lazy and uninspired. By emphazing the need to grasp the "essence" they justify discarding the "chaff," a category that includes the institutional, ceremonial, and scholastic dimensions of Zen to which the laity had long been denied access.

The similarity with the Buddhist reform movements of Southeast Asia is striking. Like Zen, Theravāda vipassanā revivals would emphasize the decadence of the clergy, the importance of meditation, and the availability of ineffable enlightenment experiences to both laymen and monks alike. The Theravāda reforms, like the Buddhist reforms in Japan, must be seen in the context of the major ideological changes precipitated by the forces of urbanization, modernization, and the spread of Western style education, all of which contributed to the rise of Protestant Buddhism. Fortunately, the Theravāda reforms have been the subject of a number of recent studies, and thus a brief overview is all that will be required here. ${ }^{32}$

The influence of the Occident in the recreation of Theravāda Buddhism is most evident in Burma and Sri Lanka, both of which were subject to periods of colonial rule. The bureaucratic needs of the colonial administration, coupled with the spread of Western style schools run by Christian missionaries, gave rise to an English educated middle-class, thoroughly inculcated in the values of their colonial mentors. This newly emergent Westernized class found themselves increasingly alienated from their cultural roots, yet at the same time they were precluded from full membership in the society of their English governors.

This Anglicized elite found itself in much the same situation as the Japanese intellectuals of the Meiji, who also availed themselves of a European style education and had come to admire Western scientific achievements. It is true, of course, that the Japanese were not themselves subject to colonial rule. Nevertheless, the experiences of Japanese intellectuals who had gone abroad and witnessed firsthand the cultural chauvinism of the West, and the experience of repeated diplomatic failure following the Japanese military victories over the Chinese in 1895 and the Russians in 
1905, convinced the Japanese that they would never gain the respect of the West despite their efforts to emulate Western ways. As mentioned above, Meiji leaders responded to the insecurity of this situation by touting the cultural and spiritual superiority of Japan, despite the fact that the forms of "traditional Japanese culture" to which they turned were all too often recast in a Western mold.

The Sri Lankan and Burmese elites responded to their colonial situation in much the same way, reasserting their traditional cultural and spiritual heritage under the banner of Theravāda Buddhism. Buddhism thus became the vehicle through which they affirmed their national identities, their cultural values, and their self-esteem. But the Buddhism of the new urban middle-class was far from the traditional Buddhism of the village. Like Meiji New Buddhism, Theravāda was refashioned in the image of postEnlightenment Christianity. In brief, the Theravāda reform emphasized: (1) the values of individualism, which included the affirmation of worldly achievement coupled with "this-worldly asceticism;" (2) a rational or "instrumental" approach to Buddhist teachings, which often involved the repudiation of the "supernatural" or "'magical" aspects of Buddhism, the rejection of "empty" ritual, and the insistence that Buddhism is a "philosophy" rather than a "religion;" (3) a new "universalism,", accompanied by a rejection of the authority of the clergy; and (4) a renewed interest in the scriptural legacy of Theravāda Buddhism. ${ }^{33}$ Indeed, Pāli scriptural materials, previously unavailable to Buddhist laity and largely ignored by the poorly educated samgha, would be used to legitimize the host of reforms associated with the Buddhist revival.

Ironically, access to the Pāli canon was made possible largely by the efforts of Western Orientalists. Prior to the nineteenth century, Pāli texts were generally unavailable in vernacular languages, or even in vernacular scripts. The impetus for Pāli studies came from British Orientalists, notably T.W. Rhys Davids, a colonial administrator in Sri Lanka who founded the Pāli Text Society in London in 1881. Many of the early subscribers to the Pāli Text Society were educated lay Sinhalese who had no access to the Buddhist canon prior to the publication of English translations around 
the turn of the century (Gombrich and Obeyesekere 1988: 210).

Even more critical to the Theravāda revival were the Theosophists. Colonel Henry Olcott and Madame Blavatsky, who formed the Theosophical Society in 1875, arrived in Sri Lanka in May 1880 and soon thereafter inaugurated the Buddhist Theosophical Society. This society constituted the first layBuddhist organization that was wholly independent of the temples and monastic hierarchy. Blavatsky and Olcott lobbied the colonial government on behalf of the Buddhist cause with great success. They also trained a generation of native Buddhist leaders, providing them with the intellectual means to defend themselves in debate with Christian missionaries. Olcott's work was continued by his Sri Lankan protégé, Anagārika Dharmapāla, who founded the Maha Bodhi Society in 1891 in order to promote the Theravāda revival in India as well as in Sri Lanka. Dharmapāla was to become the Asian spokesman for Theravāda in the West, representing his thoroughly Anglicized version of "original Buddhism" to the Chicago World Parliament of Religions in 1883.

It is in the context of this Western influenced Buddhist reformation that we must come to understand the so-called vipassana $\bar{a}$ revival in Southeast Asia. Again, I would reiterate that the practice of Buddhist meditation, even among the samgha, is not widely attested in the premodern period. Walpola Rahula has shown, for example, that by the first century B.C. the Sri Lankan samgha had come to conceive of its vocation as one of scriptural study rather than practice, and by the sixth century A.D. "Sri Lankan Buddhism had decisively rejected the ascetic hermit (tapassi) in favor of the villageand town-dwelling monks." ${ }_{34}$ While there may have been a limited tradition of meditation maintained within the samgha in Sri Lanka up until the colonial period, this tradition was evidently moribund by the end of the nineteenth century (Bechert 1966). In the course of his study of forest-monk hermitages in Sri Lanka-the tradition most closely associated with the practice of meditation-Carrithers found that "of the approximately 150 hermitages ... now in Ceylon, all but a very small handful have appeared since 1950" (Carrithers 1983: 11). Moreover, of the remaining centers, none were older than 100 years, and the relative youth of the movement can be seen in the fact that the founders of most of the hermitages 
were still alive in the 1970s. Even those scholars who suggest that there may be some continuity between the contemporary Sri Lankan forest-monk tradition and traditions going back to an earlier eighteenth-century revival concede that the style of meditation associated with the earlier tradition is very different from the methods popular in the burgeoning vipassana movement of today. ${ }^{35}$

Turning to Thailand, Tambiah suggests that there is "some evidence of an entrenched meditative tradition ... extending back at least to the Ayudhyā period," citing as evidence the Manual of a Mystic-a short manuscript most likely composed around the middle of the eighteenth century (Tambiah 1984: 70). But again, this treatise is prescriptive and liturgical in nature, and provides no evidence that there were monks who seriously strove to achieve the exalted stages enumerated therein (see Woodward 1970). Tambiah himself traces the modern indigenous Thai meditation tradition back to Phra Acharn Mun (1870-1949), a highly respected teacher considered by many to have reached the fourth and final stage of sainthood (arahat). ${ }^{36}$ While Acharn Mun may have studied with earlier teachers (notably a certain Phra Acharn Sao Kantasilo of Wat Liab), the meditation technique that Mun developed, consisting of continual contemplation of the mind and body, was largely his own. Indeed, his biography suggests that none of his contemporaries were interested in "introspective" methods of meditation, as opposed to "external" methods such as the contemplation of corpses (Tambiah 1984: 84). One of Acharn Mun's most celebrated disciples, Acharn Chā, has been responsible for training a large number of Western students, including several who have gone on to become vipassana teachers in the West. ${ }^{37}$

As influential as Acharn Mun may have been, the majority of vipassana practitioners in Thailand today follow a style of practice imported from Burma. Contemporary Burmese interest in meditation is itself often traced to Ledi Sayādaw (Saya Dala Thet, 18461923), a monk of tremendous learning who authored over seventy treatises on Pāli Buddhism. ${ }^{38}$ Ledi Sayādaw is noted for having encouraged the study of Buddhism among the laity, establishing centers throughout Burma at which lay Buddhists as well as monks could study abhidhamma and practice meditation. A number of contemporary Burmese lay-meditation movements claim to derive 
from Ledi Sayādaw, notably the tradition established by U Ba Khin (1898-1971). ${ }^{39}$

However, the method that has proven most influential-the socalled "New Burmese method" - was apparently initiated by U Nārada, also known as Mingun Jetavana Sayādaw. Nārada developed his method from his own study of the Satipatthana-sutta, undertaken at the behest of a monk he met in the hills of Sagaing. "From his own experience [Nārada] developed the principles and the details of the practice that formed the basis for those who followed him as his direct or indirect disciples" (Nyanaponika 1970: 86).

Most important among Nārada's disciplines was Bhadanta Sobhana Mahathera, better known as Mahāsī Sayādaw (19041982). As part of the pro-Buddhist policies of the newly independent Burmese government, Mahāsī was invited to Rangoon in 1949 by the Prime Minister U Nu to take charge of Thathana Yeiktha, a new government-sponsored meditation center open to the laity (Mahāsī Sayādaw 1971). The technique promoted by Mahāsī at Thathana Yeiktha proved to be a tremendous success; as of 1973 some 15,000 students are said to have trained there (Sole-Leris 1986: 129). Mahāsī's disciples have since disseminated his method throughout South and Southeast Asia, Europe, and America, and when Westerners speak of vipassana today they are often referring to the specific style of practice popularized by Mahāsī.

There is no need to detail the Mahāsī method here-any number of descriptions and first-person accounts are now available in English. ${ }^{40}$ For our purposes it is only necessary two highlight two features of Mahāsı̀'s teaching: first, Mahāsì̀s technique claims to provide the practitioner direct entry into the path of vipassana (insight into the Buddhist truths) without the need for prior training in concentration exercises (samatha) or mastery of advanced states of meditative trance (jhāna). This is most significant, as the foundation of Buddhist meditation, according to canonical sources, is the development of samatha-a task that requires a long and arduous course of training. Mahāsī naturally insists that a focused and concentrated mind is required in order to progress in vipassan $\bar{a}$, but the degree of concentration required in order to succeed at his technique is small according to traditional reckoning. ${ }^{41}$ Moreover, the 
requisite skill in samatha can be achieved in the course of one's vipassana $\bar{a}$ practice, obviating the need for preparatory samatha exercises, and thereby foreshortening and simplifying the path.

The second key feature of the Mahāsī method is the promise of quick results: "It will not take long to achieve the object, but possibly in a month, or twenty days, or fifteen days; or on rare occasions even in seven days for a selected few with extraordinary Perfection" (Mahāsī Sayādaw 1971: preface). The "object" of which Mahāsĩ speaks is none other than the experience of nibbāna. The initial "taste" of nibbanna signals the attainment of sotapatti - the first of four levels of enlightenment-which renders the meditator a "noble person" (ariya-puggala) destined for release from the wheel of existence (samsāra) in relatively short order. The claim that nibbanna can be reached in the course of a month or less is truly remarkable, given the widespread view among the traditionalists that it is almost impossible for anyone to become an ariyapuggala in modern times. Hundreds of Mahāsì's followers are believed to have reached the first stage of enlightenment, and many are thought to have attained the higher stages as well. ${ }^{42}$ As one can imagine, this has been a point of some controversy within the Theravāda world, an issue to which we will return below.

The Mahāsī Sayādaw method is the one most widely followed in Sri Lanka today. ${ }^{43}$ The technique seems to have been introduced there as early as 1939 , but it was not until the arrival of three Burmese monks in 1955, at the invitation of the Sri Lankan prime minister, that the method became popular. ${ }^{44}$ (The Sri Lankan government, like the Burmese government, was preparing at the time for the 1956 celebrations of the 2500th anniversary of the Buddha's death, and the Mahāsī method was given the official endorsement of both governments.) A number of Mahāsī's followers have also become prominent teachers in Thailand and India.

Mahāsī Sayādaw provided the Theravāda world with more than simply an easy-to-learn meditation technique; he also provided a model of an urban meditation center that became a catalyst for the spread of meditation among the laity. ${ }^{45}$ One cannot overemphasize the significance of this development: Buddhists traditionally held that meditation was a risky business that should be undertaken only under proper supervision, i.e., within the confines of the samgha. 
Prior to the modern period there was virtually no opportunity for laypersons to study meditation; indeed, as I have emphasized above, meditation practice was rare even within the samgha. Yet in the new climate of Protestant Buddhism, eminent meditation masters rushed to provide facilities for lay practitioners. They established networks of retreat centers staffed with their disciples in which laypersons and visiting foreigners could practice vipassana alongside ordained monks. ${ }^{46}$ In order to compete, even the more traditionally minded temples were often obliged to offer meditation classes for their lay patrons (Bond 1988: 173). Gombrich and Obeyesekere consider the spread of meditation among the laity to be the "greatest single change to have come over Buddhism in Sri Lanka (and indeed in the other Theravāda countries) since the Second World War." 47

Note that the very notion of a Buddhist "meditation center" was unknown before this century. Gombrich suggests that the term used in Sri Lanka to refer to such establishments-bhävana madhyasthanna-was coined after the Second World War as a literal Sanskrit translation of the English term "meditation center." "This linguistic detail mirrors a cultural trend: the institution of the meditation centre is an import, and one due largely ... to western influence"' (Gombrich 1983: 20). The spread of lay practice in turn engendered a radically new idea in the history of Buddhism, namely, that "every Buddhist should seek his own salvation in this life, which in turn means that he should practise meditation" (Gombrich 1983: 21).

The laicization of meditation both encouraged and sustained the anti-clerical sentiments of the Buddhist reformers-sentiments imbibed in large part from the coterie of English administrators and Christian missionaries who oversaw education during the colonial period. The clergy were no longer seen as having a unique purchase on Buddhist teachings. Through the efforts of European scholars the Pāli scriptures had become available to the laity in English translation. As the laity turned to lay scholars and foreign teachers for help in interpreting the scriptural corpus, they had less interest in the traditional preaching of the monks. ${ }^{48}$ Moreover, with the spread of meditation instruction in urban centers, and the widespread belief that lay meditators were routinely achieving exalted 
stages on the Buddhist path, the laity were no longer inclined to look upon the clergy as their spiritual superiors. The wisdom of the Buddha-indeed, the liberating experience of the Buddha-was made available to all.

By rendering the essence of Buddhism an "experience," the laity successfully wrested authority over the doctrine away from the clergy. The guarantee of orthodoxy was no longer rigorous adherence to the monastic code (vinaya), but rather a firsthand experience of the fruit of meditation-nirvanna. Meditation instructors with little or no formal training in canonical exegesis were free to pontificate on the meaning of Buddhist scriptures, or, alternatively, to reject the need for scriptural learning altogether. With the elevation of meditative experience, the abstruse scholastic philosophy of the abhidhamma came to be construed as an eminently empirical analysis of the world garnered through meditative insight. As such, one need not read the voluminous abhidhamma treatises to become familiar with their contents, and there are popular stories of illiterate practitioners with no prior doctrinal training who, after becoming arahats through meditative practice, correctly answered questions on abstruse points of doctrine posed by learned monks and scholars. ${ }^{49}$

As meditative practice became increasingly laicized, and the emphasis came to rest on a series of supermundane experiences attained through meditative practice, the ideology of meditation changed dramatically. "Meditation" had traditionally comprised the reenactment of the Buddha's spiritual exertions through the ritual recitation of meditation liturgies. Such exercises were typically performed in order to acquire merit and attain a more fortunate rebirth. The vipassana revival, coupled with the "Protestant" ideology of the Theravāda reforms, had the effect of rationalizing meditation; meditation was now conceived not as the ritual instantiation of Buddhahood, nor as a means to accumulate merit, but rather as a "mental discipline" designed to engender a particular transformative experience. The rationalization of meditation, coupled with the Westernized values of the middleclass patrons of urban meditation centers, led naturally to a deemphasis on the traditional soteriological goal-bringing an end to rebirth. Instead, we find an increasing emphasis on the worldly 
benefits of meditation: vipassana was said to increase physical and psychological health, to alleviate stress, to help one deal more effectively with family and business relationships, and so on. This represents the final collapse of the traditional distinction between mundane and supermundane goals-the distinction that served to legitimize the institution of the lay-supported samgha. ${ }^{50}$

The similarity between the lay Zen in post-Meiji Japan and the vipassanā revivals in Southeast Asia is striking, but not, perhaps, surprising. Indeed, analogous movements have altered the face of Buddhism in Korea and Vietnam as well. ${ }^{51}$ In each case, the threat posed by the wholesale imposition of Western values prompted Asian intellectuals to turn anew to their own cultural heritage so as to affirm and elevate their indigenous spiritual traditions. At the same time, these "indigenous" traditions were reconstituted so as to appropriate the perceived strengths of the Occident. This took the form of various reform movements that tended to reiterate the iconoclastic, anti-institutional, anti-clerical, and anti-ritual strategies of the European Enlightenment. As the reformers would have it, "true" Buddhism is not to be sought in moribund institutions, empty rituals, or dusty scriptures, but rather in a living experience. Buddhism properly understood is not a religion at all, but rather a spiritual technology providing the means to liberating insight and personal transformation. By rendering the essence of Buddhism a non-discursive spiritual experience, Buddhist apologists effectively positioned their tradition beyond the compass of secular critique.

\section{The Politics of Experience}

In the interests of demonstrating the need for a performative approach to the Buddhist rhetoric of experience, I have argued that the emphasis on meditative experiece in Buddhism may well be of recent provenance, a product of twentieth-century reforms inspired in part by Occidental models. This does not rule out the possibility, of course, that at least some monks in times past did in fact experience what we might refer to as "altered states of consciousness," "transformative insights," "mystical experiences," or what have you in the course of their monastic practice. 
(Presumably, this more likely would have been true of dhutainga monks-ascetics in the forest-monk tradition.) Moreover, there would appear to be ample evidence that those involved in the vipassana revival, or those training under Zen teachers in the Sanbōkyōdan lineage, do experience something that they are wont to call sotäpatti, jhāna, or satori. I readily concede this point; indeed, it would be surprising if those who subjected themselves to the rigors of a Buddhist meditation retreat, which can involve upwards of fourteen hours of meditation a day in an excruciatingly uncomfortable cross-legged posture, sometimes in an underground cell utterly devoid of sound and light, would not undergo some unusual and potentially transformative experiences.

My point is rather that such private episodes do not constitute the reference points for the elaborate discourse on meditative states found in Buddhist scholastic sources. In other words, terms such as samatha, vipassanā, sotāpatti, and satori are not rendered sensible by virtue of the fact that they refer to clearly delimited "experiences" shared by Buddhist practitioners. Rather, the meaning of such terminology must be sought in the polemic and ideological context in which Buddhist meditation is carried out. Once again, the most compelling arguments are not theoretical, but rather ethnographic.

Most of the practices that go under the rubric of vipassana today claim to be based on the two Satipatthanna-suttas ("Scripture on the Foundations of Mindfulness") typically used in conjunction with the Visuddhimagga. ${ }^{52}$ The Satipatthanna-sutta, however, poses a host of philological problems that render it amenable to a wide range of interpretations. Thus, when it comes to the practical application of the sutta, there is considerable difference of opinion among various contemporary vipassana $\bar{a}$ teachers. While all teachers readily concede that the aim of vipassana exercises is to develop "mindfulness" (sati), there is much disagreement concerning the precise meaning of mindfulness and the procedures most conductive to fostering it.

Debates over technique frequently employ the all-important doctrinal distinction between samatha and vipassana -concentration and insight. It is believed that virtually all Buddhist and non-Buddhist meditative techniques and experiences can be classified according to this broad schema. Indeed, the rubric of samatha and vipassana has been appropriated by some Western scholars interested in a 
universal phenomenology and typology of meditation and mystical states. A number of scholars have adopted this rubric in their attempt to analyze and classify non-Buddhist phenomena, relating samatha to "enstasis," for example, and vipassana to "ecstasis," in the hope of deducing a cause-and-effect relationship between a particular religious discipline and its psychological consequences. ${ }^{53}$

This is not the place to deal with the issue of whether or not the contemporary use of the samatha-vipassana distinction conforms to the prescriptive models found in the Buddhist canon. In fact, there are serious discrepancies in the prescriptive accounts themselves: the description of the first jhana, for example, differs depending on whether one turns to the Nikaya accounts, the Abhidhamma, or Buddhaghosa. ${ }^{54}$ This alone should give pause to those who would read canonical formulations as ostensive descriptions of meditative states.

Of more pressing concern to us is the manner in which these terms are employed by contemporary teachers, i.e., those who are presumed to have "tasted the fruits" of Buddhist meditation. While contemporary vipassana masters may employ somewhat different techniques in guiding their students, one would presume that they speak a common language when it comes to the "phenomenology" of meditation. A broad consensus among experienced meditators as to the designation of a specific meditative state, even if they disagreed as to how best to achieve such a state, would suggest the existence of a phenomenal referent. ${ }^{55}$

In fact, there is anything but consensus: the designation of particular practices and the proper identification of meditative states that supposedly result from such practices are the subjects of continued and often acrimonious debate. The only area of agreement among vipassana $\bar{a}$ teachers is that vipassana $\bar{a}$ is superior to samatha, as the former alone leads to liberation. As a result, the techniques and experiences promoted by one's competitors are often deemed to be samatha, while one's own style of practice is invariably claimed to be vipassana.

This is particularly striking, as the tradition would lead us to believe that there is a wide gulf separating samatha from vipassanā. The goal of samatha, according to scriptural sources, is an ascending series of four "material absorptions" (or "trances," rüpa-jjhāna) 
and a further series of four (or five) "immaterial absorptions" (arüpa-jjhanna). These states are held to be of an entirely different soteriological order than the states that are sought through vipassana $\bar{a}$, namely the four ariya-magga which culminate in full enlightenment. One would suppose that since the soteriological ramifications of jhanna and ariya-magga diverge so markedly, the states would be easy to distinguish on phenomenological grounds. Yet, again, there is little agreement on this point. In the living tradition such terms are often used to disparage the teachings of rival teachers: meditation masters have been known to castigate their rivals by claiming that they ignorantly mistake jhannic absorptions for sotappatti. Of course, this is but a variant of the claim that one's rival teaches samatha under the guise of vipassana $\bar{a}$.

My comments here are based in part on my own observations and conversations with vipassana teachers and students in South and Southeast Asia. Naturally, the teachers themselves, who are expected to be paragons of selflessness, compassion, and equanimity, are often hesitant to criticize their rivals in print. But the controversies that rage beneath the surface do occasionally break into the public sphere. Vimalo Bhikkhu, a Western monk who spent many years training in Southeast Asia under a variety of teachers, is a good example of how the rhetoric of meditative states operates in practice:

There are some meditation schools which claim that certain experiences occurring during the course of practice are the attainment of stream-entry [sotāpatti]. These often are remarkable meditation experiences but are in no way related to the true experience of stream-entry which is nothing other than the seeing of Nibbanna. Some schools of vipassana meditation say that a particular experience in which the meditator loses consciousness is the experience of stream-entry. This may have some significance but the genuine experience of stream-entry is something quite different. Considering these various explanations of stream-entry it really does seem that the genuine experience has become rather rare... The Buddha said that a Sotapanna could not be reborn in the lower realms of existence and would certainly within seven life-times realize complete liberation. Because of this people, seeking security, imagine all sorts of insights and unusual experiences to be streamentry and so delude themselves. (Vimalo n.d.: 64)

I do not know which teacher or teachers Vimalo may have had in mind; there are several that have been subject to criticism for being all too quick to confirm sotāpatti experiences, including 
Sunlun Sayādaw, Mahāsī Sayādaw, U Ba Khin, and their disciples. Just how quick can be seen in a pamphlet published by U Ba Khin's meditation center, entitled "Personal Experiences of Candidates (Buddhists and non-Buddhists)." 56 This pamphlet relates the case of a European businessman, "Mr. A.," who attained sotäpatti after only two days of training under U Ba Khin. $\mathrm{U}$ Ba Khin tested him, requiring that he "go into the fruition state (Phala) with a vow to rise up just after 5 minutes" (ibid.: 130). Mr. A. performed this task successfully, following which U Ba Khin tested him again, asking him to try it for fifteen minutes. Only when Mr. A. demonstrated that he could enter "Nibbāna" at will was U Ba Khin satisfied, since according to U Ba Khin's reading of the Visuddhimagga, "the real test as to whether one has become an Ariya lies in his ability to go in to the fruition state (Phala) as he may like" (ibid.: 131). U Ba Khin is aware, of course, that such a state bears a strong resemblance to jhanna absorption, but he assures us that "an experienced teacher alone will be able to differentiate between the two" (ibid.: 132).

While Vimalo refuses to name names in his denunciation of those who confuse "unusual experiences" with genuine attainment, other critics have not been as tactful. In Sri Lanka the Mahāsi method has been the subject of impassioned and somewhat rancorous attacks in various magazines and books ever since the late 1950s, i.e., from the time it first became popular. ${ }^{57}$ Traditionalist monks such as Soma Thera, Kassapa Thera, and Kheminda Thera of the Vajirārāma temple in Colombo "castigated [Mahāsī's Sri Lankan] centers for teaching unorthodox methods that threatened the true Dhamma and endangered both the institution of Buddhism and Buddhists themselves"' (Bond 1988: 163). Kassapa Thera published a series of critical essays in a book entitled Protection of the Sambuddha Sāsana (1957) that attacked Mahāsī's use of the belly as a focal point for breathing meditation (ānappanna-sati) rather than the tip of the nose, and Kheminda Thera objected to the method as an illegitimate "shortcut" that lacked canonical sanction. ${ }^{58}$ In particular, Kheminda argues from scripture that trance (jhāna) and concentration (samādhi) must be acquired prior to the practice of vipassanā.

The defenders of Mahāsī's method argued from their own 
reading of the scriptures, which they insisted recognizes a category of practitioner who proceeds directly to vipassana $\bar{a}$. They also cited as evidence the experience of yogis training under Mahāsī, and they suggested that their detractors "not rest content with the mere knowledge of the samatha-yanika method but instead practise it diligently until they attain jhanna together with abhiñña, as well as ariyabhumi. " ${ }_{59}$ Not surprisingly, the response of the traditionalists was to categorically reject the claims of their opponents to have realized legitimate stages on the path. Kassapa could argue, for example, that practitioners of the Mahāsī method "do not exhibit the calm, concentrated, happy look mentioned in the texts." ${ }_{60}$ Moreover, some practitioners of the Mahāsī method were believed to have suffered serious psychological problems as a result of the Mahāsī technique (Bond 1988: 170). The traditionalists cited passages from Mahāsī's own writings that suggest that his method could give rise to "strange physical sensations, swaying, trembling, and even loss of consciousness." ${ }_{61}$ Similar criticisms have been advanced from Western teachers as well. In an updated preface to the fifth edition of $A$ Survey of Buddhism, Sangharakshita expressed his own reservations about the Mahāsī method, which he felt could lead to "extreme nervous tension and to a schizoid state for which I coined the term 'alienated awareness.' On my return to England in $1964 \mathrm{I}$ met twelve or fourteen people who were suffering from severe mental disturbance as a direct result of practising the socalled 'Vipassana Meditation.' Four or five others had to be confined to mental hospitals', (Sangharakshita 1980: xv).

Even Gombrich and Obeyesekere get into the act, suggesting that the technique taught by Mahāsī and the curious states that occasionally result from the technique are similar if not identical to "those used for entering trance states." They go on to suggest that many of the monks, nuns, and laypersons who use the Mahāsī method "have been learning a technique that, however in fact applied, could if followed to the letter take them into trance states very like possession" (Gombrich and Obeyesekere 1988: 454). In support of this claim, Gombrich and Obeyesekere describe cases in which one and the same "altered state of consciousness" is interpreted as possession in one context (indigenous Sri Lankan spirit religion), and meditative accomplishment in another (Sri Lankan Theravāda; ibid.: 56-59). 
It should now be clear that there is no public consensus as to the application of terms that supposedly refer to discrete experiential states within the vipassana movement. Not surprisingly, the same is found to be true in Japan, where Rinzai and Sōtō monks tend to reject altogether the veracity of claims by Sanbōkyōdan practitioners to have experienced satori. (Even teachers in the Sanbōkyōdan line concede that there are differences in the "clarity and depth" of their satori experiences, an admission that again begs the issue as to the "referent" of the term satori [Kapleau 1967: 191].) The lack of consensus among prominent Buddhist teachers as to the designation not only of particular states of consciousness, but also of the psychotropic techniques used to produce them (e.g., samatha versus vipassana $\bar{a}$ ) belies the notion that the rhetoric of Buddhist meditative experience functions ostensively. ${ }^{62}$ It is apparent that even within the living Buddhist tradition a particular experiential claim must be judged on the basis of the course of training that engendered the experience and the behavior that ensued. ${ }^{63}$ Such judgments are based in turn on prior ideological commitments shaped by one's vocation (monk or layperson), one's socioeconomic background (urban middle-class or rural poor), one's political agenda (traditionalist or reformer), one's sectarian affiliation, one's education, and so on. In the end, the Buddhist rhetoric of meditative experience would appear to be both informed by, and wielded in, the interests of legitimation, authority, and power.

\section{Means and Ends}

As stated at the beginning of this article, one of the problems plaguing academic accounts of religious experience in general, and Buddhist meditative experience in particular, is the refusal to critically scrutinize the term "experience" itself. The English word is clearly multivalent, assuming a host of different meanings according to context. For our purposes we only need focus upon two more-or-less distinct usages: (1) to directly encounter, participate in, or live through; and (2) to directly perceive, observe, be aware of, or be conscious of. Note that only in the second "epistemological" sense does the term "experience" insinuate an inner or private "mental event" that eludes public scrutiny. 
There is little doubt that a host of Buddhist exegetes and reformers throughout Asian history exhorted individuals to personally engage in Buddhist practice, rather than to rest content with mere "book learning." This is clearly the intent of many Ch'an writings that arose in reaction to the scholasticism of schools such as T'ien-t'ai and Hua-yen. Ch'an teachers routinely assailed learned Buddhist scholiasts who knew the "score" but could not, or would not, "perform," just as a musician might criticize an opera critic who could not carry a tune.

Again, the injunction to practice Zen-to embody or instantiate the Buddha-dharma by participation in monastic ceremony and ritual-is not equivalent to the injunction to attain some sort of enlightenment experience. Contrary to popular belief, the Ch'an/Zen tradition was deeply suspicious of strategies that extolled "inner experience." An emphasis on personal and necessarily transient mental events reduces the sophisticated dialectic of Ch'an/Zen doctrine and praxis to a mere "means" or a set of techniques intended to inculcate such experiences. The reduction of practice to means is, in classical Ch'an terms, the sin of "gradualism" which errs in reifying Buddhahood. Not only do gradualist positions tend to reinforce craving and attachment (e.g., attachment to the path, or to the "goal" of enlightenment), but ironically, an instrumental approach to practice can actually serve to mitigate the need for practice altogether. This occurs the moment the notion that "the raft may be left behind upon reaching the other shore" is married to the Mahāyāna doctrine of universal and immanent Buddhahood. (If practice is merely a means to attain Buddhahood, and if we are all already Buddhas, then there is ultimately no need for religious training.) This is the "Alan Watts heresy," the logic of which renders all practice a form of attachment. While this position may pose as radical subitism, in reality it bespeaks of what traditional Ch'an exegetes would consider a misguided attempt to extirpate the gap between the two truths. ${ }^{64}$

There are, of course, a few premodern Ch' an and Zen masters who do appear to have emphasized a "flash of insight" or "moment of enlightenment" in their teaching, notably the Sung master Ta-hui Tsung-kao (1089-1163), and the Tokugawa Rinzai reformer inspired by Ta-hui, Hakuin Ekaku (1686-1769). A 
detailed analysis of their teachings lies beyond the scope of this article. Suffice it to say that these two influential masters had a host of lay disciples, many of whom were prominent scholars and aristocrats with no formal affiliation with Buddhism. The emphasis on a transformative moment of insight is found not so much in the sermons delivered by these masters to their monastic congregations, as in letters and essays written for their lay disciples. The stress on "spiritual experience" found in their writings appear to be accommodations to the laity - a means of making Buddhist "wisdom" accessible to students who had neither the time nor the opportunity to participate in formal monastic training. Such "conversion experiences" might be fine for lay patrons, but they were never considered full-fledged substitutes for monastic discipline.

There are thus interesting parallels between the strategies used by Ta-hui and Hakuin for handling lay disciples, and the strategies employed by the leaders of the modern lay-meditation movements examined above. By rendering Buddhist wisdom a mental event as opposed to an acquired skill, the rigors of monastic training could be circumvented. Moreover, in an age that construes religious ritual as "bad science," Buddhist religious discipline could be reconfigured as psychotherapy: Buddhist practice is thus rendered a rational attempt to alter our perception and response to the world, rather than a "magical" attempt to alter the world as such.

This strategy has enjoyed considerable success, not only in adapting Buddhism for survival in an increasingly urbanized and secularized Asia, but also in winning respectability for Buddhism among a variety of Western intellectuals and scholars. Westerners were attracted to Buddhism and Buddhist meditation by the promise of epistemological certainty acquired through systematic meditative training leading to exalted numinous states. The rhetoric of upaya (skillful means) provided Western enthusiasts with the tool they needed to shape Buddhism to their own liking: since the scriptural, ritual, and institutional forms of Buddhism were mere "skillful means" they could be abandoned at will once the centrality of meditative experience was fully appreciated.

Historians of Buddhism must be particularly circumspect in wielding the hermeneutic of upaya. The concept was first used to justify the intentional misreading of the early Buddhist canon in 
order to appropriate and subordinate Hinnayāna teachings to the new Mahāyāna revelation. The rhetorical maneuver of upāya inevitably lies in the interests of a hegemonic and universalizing discourse-invoking upaya allows the usurper to disavow difference and rupture, while arrogating the right to speak for the displaced other. ("The Buddha did not really mean what he said. What he meant was...") Scholars of Buddhism must be wary lest such patently "theological" strategies come to substitute for critical historiographic and ethnographic reconstruction.

\section{The Indeterminacy of Experience}

The urge to reduce the goal of Buddhist praxis to a mode of nondiscursive experience would seem to arise when alternative strategies of legitimation, such as the appeal to institutional or scriptural authority, prove inadequate. Breakdowns in traditional systems of authority may in turn result from a variety of historical and socioeconomic circumstances. The situation encountered repeatedly above involved an Asian nation coming into sustained contact with the culture, science, and philosophy of the West. Such contact brought in its wake the scourge of cultural relativism. By privileging private spiritual experience Buddhist apologists sought to secure the integrity of Buddhism by grounding it in a transcultural, trans-historical reality immune to the relativist critique.

The central feature of private experience that allowed it to play this role is precisely its unremitting indeterminacy. Indeed, Buddhist meditative experience is often circumscribed in terms of its "non-discursive" or "non-intellectual" character. (Note the mischief at work here: the fact that nothing can be said of a particular experience-i.e., its ineffability-cannot in and of itself constitute a delimiting characteristic.) At the same time, the rhetoric of experience tacitly posits a "place" where signification comes to an end, variously styled "mind," " "pure consciousness," the "mirror of nature," or what have you. The category "experience" is, in essence, a mere placeholder that entails a substantive if indeterminate terminus for the relentless deferral of meaning. And this is precisely what makes the term so amenable to Buddhist ideological appropriation. 
The Buddhist strategy involves extolling experience as a superior form of knowledge, i.e., superior to "second-hand" knowledge gleaned from teachers or texts. Second-hand knowledge is invariably fickle, being subject to the vagaries of interpretation, not to mention the threat of empirical refutation. In contrast, first-hand experience-construed as that which is "immediately present" - is both irrefutable and indubitable. Indeed, one of the defining characteristics of Buddhist "enlightenment experiences," according to traditional sources, is precisely the elimination of doubt. Yet ironically, such certainty can be gained only at the expense of discursive meaning and signification. This contributes to the confusions and controversies that plague many of the modern Buddhist revival movements mentioned above.

One way to mask the indeterminacy of "private mental events" is by insisting on an isomorphic relationship between meditative procedure and meditative experience. We have seen that the identification of a particular altered state is often determined by a critical appraisal of the technique that occasioned it. Moreover, contemporary exegetes use terms such as vipassan $\bar{a}$ and samatha to refer both to specific meditative techniques and to the states they supposedly engender, thereby finessing the logical gap that separates them. In etic terms, Buddhist meditation might best be seen as the ritualization of experience: it doesn't engender a specific experiential state so much as it enacts it. In this sense Buddhist mārga treatises are not so much maps of inner psychic space as they are scripts for the performance of an eminently public religious drama.

The public nature of Buddhist meditative ritual is readily confirmed when we attend to the emphasis placed on the formal authentication and certification of so-called enlightenment experiences - a convention somewhat at odds with the dogma that enlightenment obviates doubt. The legitimacy and orthodoxy of a particular meditative experience is guaranteed not only by strict adherence to prescribed technique, but also by ceremonial acts intended to "authorize" or "certify" one's spiritual accomplishment to the community at large. In sects where experience has become the exclusive criteria for assessing one's spiritual development (as opposed to doctrinal learning, ritual mastery, or vocational maturity), such rituals take on paramount importance. Thus 
the Sanbōkyōdan has instituted a ritual held at the end of meditation retreats in which those who experienced satori are brought before the entire congregation and later presented with a diploma certifying their accomplishment.

In Southeast Asia authentication often requires the complicity of scriptural exegetes who are called upon to attest to the orthodoxy of one's meditative accomplishment. Buddhist saints (meditation virtuosos) are examined on their spontaneous apprehension of Buddhist doctrine-an apprehension supposedly gained not through prolonged textual study but rather through their direct perception of the workings of psycho-physical reality. There is thus a symbiotic if not collusive relationship between specialists in doctrine and specialists in meditation: while meditation masters require scholarmonks to attest to the legitimacy of their experiences, scholarmonks need meditation masters to experientially verify the truth of the teachings enshrined in the scriptures. In this case the rhetoric of experience is wielded in a ritualized examination that does not wrest control from the scripturalists, but rather bears witness to the "empirical" foundations of the canonical tradition.

Such public enactments of enlightenment-ceremonial affirmations of the reality of nirvāna in the here and now-constitute the proper domain in which to situate the Buddhist rhetoric of experience. Whatever ineffable experiences might transpire in the minds of Buddhist meditators, such events do not, and indeed cannot, impinge upon the ideologically charged public discourse concerning experience and enlightenment. This brings us back to Frank Ramsey's laconic critique of Wittgenstein which I used as an epigraph to this article: "what we can't say we can't say and we can't whistle either." The Buddhists, it would seem, are no better at whistling than are we.

The University of Michigan

ROBERT H. SHARF

Department of Asian Languages and Cultures

3070 Frieze Building

Ann Arbor MI 48109, USA 
* Research for this paper was supported in part by a grant from the Social Sciences and Humanities Research Council of Canada. An earlier draft was presented at the panel "The Rhetoric of Experience" held at the annual meeting of the American Academy of Religion, San Francisco, November 21, 1992. I would like to thank Johannes Bronkhorst, Janet Gyatso, Donald Lopez, Marina Vitkin, and Thomas Young for their comments and suggestions on earlier drafts .

1 Conze 1967: 213. Conze is confident enough to declare that he "cannot imagine any scholar wishing to challenge this methodological postulate."

2 While I use the more "generic" Sanskrit here ('samatha, vipaśyanā, etc.), when dealing with contemporary Theravāda reform movements below I use the equivalent Pāli terms (samatha, vipassanā).

${ }_{3}$ See, for example, the essays in Katz ed. 1978, 1983, and 1992; Forman ed. 1990; as well as Barnard 1992; Forman 1993; Katz 1882 and 1985; King 1988; Proudfoot 1985; Scholem 1969: 5-31; Shear 1994; and Smart 1977.

${ }^{4}$ In so far as Buddhist material can be seen as contributing to this debate, I feel that Gimello has cogently shown that advanced Buddhist meditation involves a discriminative or analytic component; Buddhist vipaśyana meditation "consists in the meditatively intensified reflection upon the basic categories of Buddhist doctrine and in the application of them to the data of meditative experience.... The final key to liberation for the Buddhist lies with this analytic destruction of false views (Gimello 1978: 188; see also Gimello 1983). I will briefly return to Gimello's analysis below.

${ }^{5}$ On projection and transference in the study of Buddhism see esp. the analysis in Faure 1991.

${ }^{6}$ Apropos of Herrigel's "romanticism," note that he joined the Nazi party soon after his return to Germany, and he remained loyal to the Nazi cause throughout the course of the war (Scholem 1961: 96).

7 This constitutes number 7 in the Mahāsāmghika list of pācattika offenses, and number 8 in the corresponding Mūlasarvāstivādin list of pāyantika offenses (Prebish 1975: 74-75). On the effects of this prohibition in contemporary Sŏn monasticism see Buswell 1992: 10.

${ }^{8}$ John Strong makes the same point with regard to the Buddhist duṣkrta offence, which prohibits Buddhist monks from performing magical feats in public (Strong 1979: 75); see also the discussion in Faure 1991: 103.

${ }^{9}$ For a full account see Griffiths 1986 and 1990.

10 There are, of course, several varieties of Western idealism that share aspects of Mahāyāna idealism, yet that make no appeal to privileged meditative insight (Berkeley and Hegel come to mind). Note that Schmithausen goes on to cite the Pratyutpannasamādhisuttra in support of his thesis, paraphrasing from the text as follows: "Just as a man, awaking from a dream, comprehends that all phenomena are illusory like dream visions, in the same way the reflection of the Bodhisattva who understands that in his meditation he did not really meet the Buddha culminates in the intuition of universal ideality" (Schmithausen 1976: 246). Remarkably, Schmithausen cites this text in support of his claim that, "the thesis of universal idealism originated from the generalization of a situation observed in the case of objects visualized in meditative concentration, i.e., in the context of spiritual practice" (ibid.: 247). Yet this scripture suggests quite the opposite, in so far as it succeeds in explicating a doctrinal point by drawing an analogy to dreaming - an experience common to all irrespective of one's spiritual practice.

11 I am not the first to draw attention to this; Donald Lopez and Johannes Bronkhorst have made similar observations concerning the nature of Buddhist tex- 
tual sources (see Lopez 1992: 148, and Bronkhorst 1993). This remains a minority position, however, among scholars of Indo-Tibetan Buddhism.

12 A relatively comprehensive list of such attainments can be found in the Iddhividha-niddesa chapter of the Visuddhimagga; see Buddhaghosa 1976: 409-471.

13 See the comments in Halbfass 1988: 393.

${ }_{14}$ See Buddhaghosa 1976: 1.477 , and the translator's comments, p. xix.

15 See the comments to this effect in McRae 1992: 349. Note that Chih-i's editor, Kuan-ting (561-632), is now considered to have had a major role in shaping this text, drawing freely from the writings of the San-lun exegete Chi-tsang (549-623). Kuan-ting's preface claims that Chih-i expounded on the dharma teachings that Chih-i "practiced in his own mind" (T.1911: 46.1b13). No such claim, however, is to be found in the body of the work itself. Moreover, orthodox T'ien-t'ai commentators concede that Chih-i did not attain a particularly high spiritual rank during his lifetime. (See, for example, Chan-jan's Chih-kuan fu-hsing ch'uan-hung chüeh, T.1912: 46.148c11-12.)

16 It is noteworthy that the few major figures in this area who do claim to speak from personal experience, such as Aldous Huxley, tend to rely upon psychotropic drugs to induce their "mystical experiences." In the current context this begs the issue-there is no prima facie reason to associate drug-induced "altered states of consciousness" with the purported goals of Buddhist praxis.

17 On the manner in which Buddhist sūtras were treated as cult objects see esp. Schopen 1975 .

18 See, for example, Carrithers 1983: 222-223, and Gombrich 1971: 322.

19 Gombrich 1971: 322; see also the overviews in Bunnag 1973; Gunawardana 1979; Malalgoda 1976; Mendelson 1975; Obeyesekere 1981; Spiro 1970; and Tambiah 1970, 1976, and 1984.

${ }^{20}$ See, for example, Bond 1988; Carrithers 1983; and Gombrich and Obeyesekere 1988.

21 On this traditional distinction see esp. Gombrich 1971: 269.

22 See Carrithers 1983: 19. Carrithers is to be lauded for debunking the notion that "the founding of the hermitages [in Sri Lanka] was informed by the monks' experience in meditation." He says that this "totally wrong" presupposition "rests upon the notion of the primacy of religious experiences, preferably spectacular ones, as the origin and legitimation of religious action. But this presupposition has a natural home, not in Buddhism, but in Christian and especially Protestant Christian movements, which prescribe a radical conversion experience as the basis of Church membership" (ibid.: 18). Carrithers equivocates, however, when he comes to analyze the nature of Theravāda meditation techniques. On the one hand, he rejects "an extreme view of the ineffability of the spoken word and of the uniqueness of experience, or of historical relativity" (ibid.: 223-224), and he seems willing to accept certain fundamental claims made on behalf of the Theravāda system: "To practice insight meditation is to see-or perhaps better, to discover - the psychological realities described in Buddhist doctrine in one's own experience" (ibid.: 226). On the other hand, he concedes that there are difficulties entailed in "connecting [Buddhist] doctrinal categories with immediate experience"' (ibid.: 229).

${ }^{23}$ As William Bodiford has pointed out, Manzan Dōhaku (1636-1714), the Tokugawa Sōtō reformer, cited none other than the founder of Japanese Sōtō Zen, Dōgen (1200-1253), when arguing that "dharma transmission can occur whether or not the disciple is enlightened" (Bodiford 1991: 144). Manzan further rejected the notion of a "self-enlightened Zen Master," since this would imply a rejection 
of the central Buddhist teaching of causality (ibid.). It would be a mistake to think of Manzan's reforms as the unfortunate result of a long process of "routinization" or "ritualization": the fact is that Ch'an/Zen "dharma inheritance" entailed the transmission of nothing less than the Buddha-mind, which, according to the logic of Ch'an/Zen doctrine, is already possessed by all. As such, formal transmission actually involved the ritual investiture of a student in an institutionally certified genealogy (see Foulk and Sharf 1993/94).

${ }^{24}$ Sections of the following discussion on Meiji Buddhism and D.T. Suzuki's "Zen" are taken directly from my article "The Zen of Japanese Nationalism" (Sharf 1995a); see also Sharf 1995b.

${ }_{25}$ Nishida 1965-66: 1.9; trans. Dilworth 1969: 95-96.

${ }^{26}$ This exalted experience was also, according to Suzuki, the essence of all Japanese cultural artifacts-a claim that had the effect of "spiritualizing" the nation as a whole. See the full discussion in Sharf 1995a.

${ }^{27}$ The Society's name was arrived at as follows: " 'F' stands for the Formless self awakening itself, 'A' for taking the standpoint of All humankind, and 'S' for creating Suprahistorical history" (FAS Society Journal Autumn 1987, 18).

${ }^{28}$ A more comprehensive description of the F.A.S. society can be found in Sharf 1995a.

${ }^{29}$ See Sharf n.d. for a full discussion of these issues.

30 Yasutani himself took a great interest in training Westerners, and his interest was continued by his successor, Yamada Kōun (1907-1989). Both Yasutani and Yamada made a number of trips to the West, certifying many Western disciples as authorized teachers in their lineage. The Zen teachings of H.M. EnomiyaLassalle (1898-1990), Philip Kapleau (1912-), Robert Aitken (1917-), Maezumi Taizan (1930-), and Eido Tai Shimano (1932-), bear the imprint of Yasutani's tutelage. Enomiya-Lassalle was the first to hold Zen retreats in Germany, and continued to be active as a Zen teacher in Europe and Japan until his death in 1990. The latter four each went on to establish Zen training centers in the United States.

31 Obeyesekere coined the term "Protestant Buddhism" in 1970 in a discussion of the revival of Theravāda in late nineteenth-century Ceylon (Obeyesekere 1970).

${ }^{32}$ See esp. Bond 1988; Carrithers 1983; Gombrich and Obeyesekere 1988; and Malalgoda 1976.

${ }^{33}$ For a detailed analysis of the characteristics of the Theravāda reforms see esp. Ames 1963; Bond 1988; and Gombrich and Obeyesekere 1988.

34 Tambiah 1984: 54, citing Rahula 1956: 158.

35 The earlier revival was stimulated by monks coming to Sri Lanka from Siam to teach meditation. The techniques would have involved contemplation of the qualities of the Buddha, contemplation of the thirty-two parts of the body, and so on. See the comments in Gombrich 1971: 281-282, and Tambiah 1984: 58-59.

${ }^{36}$ See his biography in Phra Acharn Maha Boowa Hyanasampanno 1976, and the study by Tambiah 1984: 81-110.

37 Among them are Jack Kornfield, author of Living Buddhist Masters (1977), and Sumedho Bhikku, founder of Chithurst Forest Monastery in Hampshire, England. See also Ward 1990, for an engaging account of daily life in a branch monastery established by Acharn Chā specifically for training foreigners.

${ }^{38}$ A brief biography and English translations of eight of his manuals can be found in Ledi Sayadaw 1965.

${ }^{39} \mathrm{U}$ Ba Khin, who served in a number of important posts in U Nu's postindependence government, studied meditation under the layman Saya Thet Gyi, 
a student of Ledi Sayādaw. U Ba Khin apparently experimented with different techniques throughout his career, all of which focused primarily on bodily sensations. He established a small meditation center in a suburb of Rangoon in 1952, where he trained lay Burmese as well as foreigners. Due to the influence of some of his foreign disciples, his technique has become far better known in the West than it is in his native Burma. S.N. Goenka (1924- ) has been particularly active, establishing meditation centers in India, America, and Australia, and leading lay retreats throughout the world. For brief biographies of $U$ Ba Khin and Goenka, as well as descriptions of their technique, see King 1980: 125-132; Nottingham 1960; and Sole-Leris 1986: 136-153.

40 See for example, Kornfield 1977: 51-81; Mahāsī Sayādaw 1971; Nyanaponika 1970 and 1972; and Shattock 1972.

41 Practitioners of Mahāsī's method need only reach the stage of "access- or Neighbourhood-Concentration"' (upacāra-samādhi; Nyanaponika 1970: 89).

42 Mahāsī Sayādaw seems to have considered the attainment of sotāpatti a necessary and sufficient condition for becoming an "authorized" teacher of his method. Given the fact that many who attain sotäpatti possess neither the time nor the inclination to become teachers, the large number of Mahāsī disciples who are in fact teaching throughout the world illustrates just how common sotäpatti has become in the "Mahāsī school."

${ }^{43}$ Note that Anagārika Dharmapāla had previously tried to "revive" meditation on the basis of textual materials. He had come upon the Manual of a Mystic in 1892, and used that text along with others in formulating his own system of meditation which he then propagated among his lay followers. See Carrithers 1983: 240, and Gombrich and Obeyesekere 1988: 237-238.

${ }^{44}$ For an account of the meditation revival in Ceylon see esp. Gombrich 1983; Carrithers 1983: 222-246; and Gombrich and Obeyesekere 1988: 238.

${ }^{45}$ One of the prominent Mahāsī centers in Sri Lanka, opened in 1956 at Kanduboda, provides meditation classes in English as well as Sinhalese, making the practice available to foreigners as well (Gombrich and Obeyesekere 1988: 238).

46 Although I have mentioned only a handful of contemporary teachers above, the reader should keep in mind that there are several dozen prominent teachers active in Burma, Thailand, and Sri Lanka, many of whom propagate techniques of their own devising based on their personal practice as well as their knowledge of Buddhist scriptural sources. Many such teachers, including Sunlun Sayādaw (1878-1952) in Burma, and Achaan Buddhadāsa (1906-1993) in Thailand, have considerable followings.

47 Gombrich and Obeyesekere 1988: 237; see also Swearer 1970.

48 Bond 1988: 183. Gombrich and Obeyesekere note that "What is printed in Sinhala in newspapers, books, and above all in school textbooks derives largely from the English-language Orientalist view of Buddhism"' (1988: 448). Bond similarly notes that "Sinhalese Buddhists accept these foreign teachers and their ideas in the same way and for the same reason that earlier Buddhists accepted Colonel Olcott: Because foreigners who espouse one's own tradition enhance its credibility and increase one's appreciation of it" (Bond 1988: 191).

49 One such case is that of Sunlun Sayādaw (born Maung Kyaw Din); see the account in Kornfield 1977: 85, and King 1980: 138.

50 See the comments in Gombrich and Obeyesekere 1988: 237, and 273.

51 On nineteenth-century samgha reforms in Korea see Buswell 1992: 25-30. The Korean reforms, which were stimulated by the "New Buddhism" of Japan as well as by anti-colonialist (anti-Japanese) sentiments, were led by intellectuals 
such Han Yongun (1879-1944). Buswell notes that Yongun's vision of reform was profoundly influenced by both his study of Western thought and his travels abroad. Like his Meiji counterparts, Yongun came to see the Korean Buddhist tradition of his day as "degenerate," and he "called on Korean Buddhism to evolve along what he termed modern, scientific lines, while still drawing from its wellspring in Asian spiritual culture"' (Buswell 1992: 26). On the Vietnamese reforms see esp. the remarks by Heinz Bechert and Vu Duy-Tu (1976: 190-193). The Vietnamese Buddhist teacher best known in the West, Thich Nhat Hanh, similarly propounds a somewhat "Protestantized" Buddhism. Thich Nhat Hanh had been a scholar of religion at Van Hanh Buddhist University in Saigon, and was active in the peace movement in Vietnam until barred from re-entry to his country in 1966 after a lecture tour to the West. He was also among the founders of the socially active Tiep Hien Order begun in Vietnam in 1964. Note the first of the Order's fourteen precepts: "Do not be idolatrous about or bound to any doctrine, theory or ideology, including Buddhist ones. Buddhist systems of thought must be guiding means and not absolute truth" (Vajradhatu Sun Dec. 1985Jan. 1986: 2). The seventh precept, which enjoins concentration on breathing as well as mindfulness meditation, is considered the "core" of the Tiep Hien precepts.

${ }_{52}$ Dìgha-nikāya 22, and Majjhima-nikāya 10.

${ }_{53}$ See, for example, Goleman 1977; Kohn 1987: 65-73, and 1989: 193-195; Ornstein 1972; Shapiro 1984: 6; Walsh 1984 and 1993.

${ }^{54}$ See the discussions in Bronkhorst 1986; Bucknell 1991; Cousins 1973; Griffiths 1983b; and Stuart-Fox 1989. In addition to scriptural discrepancies over the meaning of the term jhanna, there is evidence that contemporary use of the term vipassana diverges significantly from canonical norms. While "access concentration" was traditionally seen as prerequisite for the development of vipassana (Cousins 1973: 123), there was clearly an analytic component to vipassana practice as well: it involved controlled reflection upon (or recollection of) central Buddhist tenets such as impermanence or non-self. This more "discursive" element is lacking in some contemporary techniques that go under the rubric of vipassana $\bar{a}$, rendering them closer to what would have traditionally been classified as samatha. This point has been made by some Asian critics of the vipassanā movement (see below).

${ }^{55}$ In a recent article on jhāna, Roderick Bucknell claims that ethnographic evidence points to just such a consensus, and that this consensus constitutes empirical evidence for Buddhaghosa's account: "It can be fairly readily confirmed that Buddhaghosa's account is generally accurate as a description of the meditative practice. Numerous practicing meditators, particularly in the Buddhist countries of Southeast Asia, routinely experience many of the stages Buddhaghosa describes" (Bucknell 1993: 338). Bucknell immediately goes on to admit, however, that "such meditators and their teachers do not necessarily use Buddhaghosa's terminology; however, some of the stages they describe can be readily recognized and correlated with his account" (ibid.) The main piece of evidence adduced in support of this striking claim is a series of conversations with a meditation master from Bangkok, Chaokhun Rajasiddhimuni (ibid.: n. 28). Bucknell is sufficiently confident of the empirical foundations of Theravāda meditation exercises to suggest that "Researchers wishing to investigate the matter at first hand can do so by taking up intensive meditation themselves. Such experimentation will support the claim that all meditators pass through essentially the same sequence of stages, provided they pursue the practice intensively and persistently enough, in a suitable environment, and with competent guidance"' (ibid.: 388-389). As we 
will see below, there is in fact little agreement among teachers in Southeast Asia as to the identification and designation of specific meditative states. Indeed, the question as to who is able to offer "competent guidance" is a contentious subject among seasoned meditators.

56 The pamphlet is reproduced in part in King 1980: 126-132.

57 See esp. the documents collected in Buddha Sāsana Nuggaha Organization 1979, as well as the discussions in Bond 1988: 162-171; Carrithers 1983: 240-243; and Gombrich and Obeyesekere 1988: 454.

${ }^{58}$ Kheminda believed the technique heterodox as it did not follow the traditional three-stage path, consisting of perfection of morality, concentration, and wisdom (sila, samädhi, and pañ $\tilde{a}$ ). Kheminda's views were first published in the pages of World Buddhism, and are reproduced in part in Buddha Sāsana Nuggaha Organization 1979, along with rejoinders by prominent disciples of Mahāsī Sayādaw. See also Kheminda 1980, and the discussion in Bond 1988: 164-171.

59 Buddha Sāsana Nuggaha Organization 1979: 35. Note also the following: "The Ven. Mahāsī Sayādaw, on the strength not only of Ceylon commentaries, etc. but also of the practical experiences of the yogis, has, with the best of intentions, written the above-mentioned treatise on Buddhist meditation" (ibid.: 29-30).

60 Kassapa 1957: 12, cited in Bond 1988: 170.

${ }^{61}$ Gombrich and Obeyesekere 1988: 454. Objections to the Mahāsī method do not emerge from traditionalist quarters alone. I was informed by two teachers associated with U Ba Khin's center in Rangoon that experiences certified as sotāpatti by Mahāsī and his disciples are not the real thing. This is noteworthy, as many of U Ba Khin's own disciples are believed to have attained the stage of sotäpatti, and thus their objections do not stem from the traditional belief that the attainment of sotäpatti is rare. Note also the personal account by Eric Lerner, an American who trained at U Ba Khin's center under his successor Sayama. Lerner recounts how, after a period of training in Burma, he retreated to a forest monastery in Sri Lanka where he experienced what he took to be sotapatti. Upon returning to Burma he was told, much to his chagrin, that it was only a "taste" of jhäna and that it was more of a hindrance than a help (Lerner 1977).

${ }_{62}$ See also King 1980: 143-144, where he discusses the problems in characterizing Sunlun's technique as either vipassanā or samatha. Buswell has similar problems in situating Sŏn hwadu practice within the "classical" Buddhist schema of vipassanā-samatha: "hwadu is not intended to generate a state of samādhi but a state in which both the calmness of samādhi and the perspicuity of prajñā are maintained.... If one were to try to place the state of mind engendered through kanhwa practice in the stages in Buddhist meditation outlined in the Theravāda school, I believe it would be rather more akin to 'access concentration' (upacāra-samädhi), which accompanies ten specific types of discursive contemplations" (Buswell 1992: 159).

${ }^{63}$ In U Ba Khin's analysis of Mr. A's phala experience, for example, U Ba Khin includes a detailed description of the sequence of Mr. A.'s training, despite the fact that the course of training lasted a mere three days (King 1980: 130-132). The argument is explicit: if the training that led to the experience conformed to canonical descriptions of the path to nibbanna, then the resultant experience must indeed have been nibbāna. Another contemporary authority, Saddhātissa, warns that even if a meditator finds his sessions improving dramatically, such that "he is attaining trance-like states of concentration," if there is "no change in his daily 
life ... it may well be that what he has been calling tranquillity and concentration is, in fact, a state of self-induced hypnotism" (cited in Cousins 1973: 126).

${ }^{64}$ There are, in fact, early precedents for the "Watts heresy." According to the T'ang dynasty exegete Tsung-mi (780-841), the Ch'an master Wu-chu (714-774) of the Pao-t'ang school in Szechwan took the iconoclastic and antinomian rhetoric of Ch'an literally, such that he refused to transmit the precepts and rejected most of the liturgical and ritual procedures considered integral to the monastic tradition. No doubt this contributed to the quick demise of his lineage. See the account in Broughton 1983: 38-40.

\section{REFERENCES}

Note: References to works in the 100 volume Taishō edition of the Buddhist canon (Taishō daizōkyō, ed. Takakusu Junjirō and Watanabe Kaigyoku, Tokyo: Taishō issaikyō kankōkai, 1924-1932), are indicated by the text number ("T.") followed by the volume, page, register $(\mathrm{a}, \mathrm{b}$, or $\mathrm{c})$, and, when appropriate, the line number(s).

Ames, Michael

1963 "Ideological and Social Change in Ceylon." Human Organization 22 (1): 45-53.

Barnard, G. William

1992 "Explaining the Unexplainable: Wayne Proudfoot's Religious Experience." Journal of the American Academy of Religion 60 (2): 231-256.

Bechert, Heinz

1966 Buddhismus, Staat und Gesellschaft in den Ländern des Theravāda Buddhismus, vol. 1, Allgemeines und Ceylon. Hamburg: Schriften des Instituts für Asienkunde.

Bechert, Heinz, and Vu Duy-Tu

1976 "Buddhism in Vietnam." In Buddhism in the Modern World, ed. Heinrich Dumoulin and John C. Maraldo, 186-193. New York: Collier Books.

Bell, Catherine

1992 Ritual Theory, Ritual Practice. New York: Oxford University Press.

Beyer, Stephan

1973 The Cult of Tārā: Magic and Ritual in Tibet. Berkeley and Los Angeles: University of California Press.

Bodiford, William M.

1991 "Dharma Transmission in Sōtō Zen: Manzan Dōhaku's Reform Movement." Monumenta Nipponica 46 (4): 423-451.

Bond, George D.

1988 The Buddhist Revival in Sri Lanka: Religious Tradition, Reinterpretation and Response. Columbia: University of South Carolina Press.

Bronkhorst, Johannes

1986 The Two Traditions of Meditation in Ancient India. Alt- und Neu-Indische Studien, Bd. 28. Stuttgart: Franz Steiner.

1993 Review of Ilkka Pyysiäinen's Beyond Language and Reason: Mysticism in Indian Buddhism (Helsinki: Suomalainen Tiedeakatemia). Asiatische Studien/Études Asiatiques 47 (4): 709-715. 
Broughton, Jeffrey

1983 "Early Ch'an Schools in Tibet." In Studies in Ch'an and Hua-yen (Kuroda Institute Studies in East Asian Buddhism, no. 1), ed. Robert M. Gimello and Peter N. Gregory, 1-68. Honolulu: University of Hawaii Press.

Bucknell, Roderick S.

1993 "Reinterpreting the Jhannas. "' Journal of the International Association of Buddhist Studies 16 (2): 375-409.

Buddhaghosa

1976 The Path of Purification (Visuddhimagga). Translated from the Pāli by Bhikkhu Nyānamoli. 2 vols. Berkeley: Shambhala Publications. First published in Sri Lanka in 1956.

Buddha Sāsana Nuggaha Organization, ed.

1979 Satipatthāna Vipassanā Meditation: Criticisms and Replies. Rangoon: Buddha Sāsana Nuggaha Organization.

Bunnag, Jane

1973 Buddhist Monk, Buddhist Layman: A Study of Urban Monastic Organization in Central Thailand. Cambridge Studies in Social Anthropology, no. 6. Cambridge: Cambridge University Press.

Buswell, Robert E., Jr.

1992 The Zen Monastic Experience: Buddhist Practice in Contemporary Korea. Princeton: Princeton University Press.

Buswell, Robert E., Jr., and Robert M. Gimello, eds.

1992 Paths to Liberation: The Mārga and Its Transformations in Buddhist Thought. Kuroda Institute Studies in East Asian Buddhism, no. 7. Honolulu: University of Hawaii Press.

Carrithers, Michael

1983 The Forest Monks of Sri Lanka: An Anthropological and Historical Study. Delhi: Oxford University Press.

Conze, Edward

1956 Buddhist Meditation. Ethical and Religious Classics of East and West, no. 13. London: George Allen and Unwin Ltd.

1967 Thirty Years of Buddhist Studies. London: Bruno Cassirer.

Cousins, L.S.

1973 "Buddhist Jhāna: Its Nature and Attainment According to the Pali Sources," Religion 3: 115-131.

Cox, Collett

1992 "Mindfulness and Memory: The Scope of Smrti from Early Buddhism to the Sarvāstivādin Abhidharma." In In the Mirror of Memory: Reflections on Mindfulness and Remembrance in Indian and Tibetan Buddhism, ed. Janet Gyatso, 67-108. Albany: State University of New York Press.

Dilworth, D.A.

1969 'The Initial Formations of 'Pure Experience' in Nishida Kitarō and William James." Monumenta Nipponica 24 (1-2): 93-111.

Faure, Bernard

1991 The Rhetoric of Immediacy: A Cultural Critique of Chan/Zen Buddhism. Princeton: Princeton University Press.

Forman, Robert K.C.

1993 "Mystical Knowledge: Knowledge by Identity." Journal of the American Academy of Religion 61 (4): 705-738. 
Forman, Robert K.C., ed.

1990 The Problem of Pure Consciousness: Mysticism and Philosophy. New York and Oxford: Oxford University Press.

Foulk, T. Griffith, and Robert H. Sharf

1993/94 "On the Ritual Use of Ch'an Portraiture in Medieval China." Cahiers d'Extrême-Asie 7: 149-219.

Gimello, Robert M.

1978 "Mysticism and Meditation." In Katz ed. 1978: 170-199.

1983 "Mysticism in Its Contexts." In Katz ed. 1983: 61-88.

Goleman, Daniel

1977 The Varieties of the Meditative Experience. New York: E.P. Dutton.

Gombrich, Richard F.

1971 Precept and Practice: Traditional Buddhism in the Rural Highlands of Ceylon. Oxford: Oxford University Press.

1983 "From Monastery to Meditation Centre: Lay Meditation in Modern Sri Lanka." In Buddhist Studits: Ancient and Modern (Collected Papers on South Asia, no. 4), ed. Philip Denwood and Alexander Piatigorsky, 20-34. London: Curzon Press.

Gombrich, Richard, and Gananath Obeyesekere

1988 Buddhism Transformed: Religious Change in Sri Lanka. Princeton: Princeton University Press.

Griffiths, Paul John

1981 "Concentration or Insight: The Problematic of Therāvada Buddhist Meditation-Theory." Journal of the American Academy of Religion 49 (4): 605-624.

1983a "Indian Buddhist Meditation-Theory: History, Development and Systematization." Ph.D. dissertation, University of Wisconsin, Madison.

1983b "Buddhist Jhāna: A Form-Critical Study." Religion 13: 55-68.

1986 On Being Mindless: Buddhist Meditation and the Mind-Body Problem. La Salle, Illinois: Open Court.

1990 "Pure Consciousness and Indian Buddhism." In Forman ed. 1990: 71-97.

Gunawardana, R.A.L.H.

1979 Robe and Plough: Monasticism and Economic Interest in Early Medieval Sri Lanka. The Association for Asian Studies Monographs and Papers, no. 35. Tucson: The University of Arizona Press.

Halbfass, Wilhelm

1988 "The Concept of Experience in the Encounter Between India and the West." In his India and Europe: An Essay in Understanding, 378-402. Albany: State University of New York Press.

Herrigel, Eugen

1971 Zen in the Art of Archery. Introduction by D.T. Suzuki, trans. R.F.C. Hull. New York: Vintage Books.

Jaini, Padmanabh S.

1992 "Smrti in the Abhidharma Literature and the Development of Buddhist Accounts of Memory of the Past." In In the Mirror of Memory: Reflections on Mindfulness and Remembrance in Indian and Tibetan Buddhism, ed. Janet Gyatso, 47-60. Albany: State University of New York Press.

James, William

1961 The Varieties of Religious Experience: A Study in Human Nature. New York: Collier Books. 
Kapleau, Philip

1967 The Three Pillars of Zen: Teaching, Practice, Enlightenment. Boston: Beacon Press.

Kassapa Thera

1957 Protection of the Sambuddha Säsana: A Collection of Articles on Meditation. Colombo: Henry Prelis.

Katz, Steven T.

1978 "Language, Epistemology, and Mysticism." In Katz ed. 1978: 22-74.

1982 “"Models, Modelling and Mystical Training." Religion 12: 247-75.

1983 “'The 'Conservative' Character of Mystical Experience.' In Katz ed. 1983: 3-60.

1985 "Recent Work on Mysticism." History of Religions 25 (1): 76-86.

Katz, Steven T., ed.

1978 Mysticism and Philosophical Analysis. New York: Oxford University Press.

1983 Mysticism and Religious Traditions. New York: Oxford University Press.

1992 Mysticism and Language. New York: Oxford University Press.

Kheminda Thera

1980 The Way of Buddhist Meditation. Colombo: Lake House Publishers.

King, Sallie B.

1988 "Two Epistemological Models for the Interpretation of Mysticism." Journal of the American Academy of Religion 56 (2): 257-279.

King, Winston L.

1980 Theravāda Meditation: The Buddhist Transformation of Yoga. University Park: Pennsylvania State University Press.

Kohn, Livia

1987 Seven Steps to the Tao: Sima Chengzhen's “Zuowanglun." Monumenta Serica Monograph Series, no. 20. Nettetal: Steyler Verlag.

1989 "Taoist Insight Meditation-The Tang Practice of Neiguan." In Taoist Meditation and Longevity Techniques (Michigan Monographs in Chinese Studies, no. 61), ed. Livia Kohn, 193-224. Ann Arbor: University of Michigan, Center for Chinese Studies Publications.

Kornfield, Jack

1977 Living Buddhist Masters. Santa Cruz: Unity Press.

Ledi Sayadaw

1965 The Manuals of Buddhism (The Expositions of the Buddha-Dhamma). Rangoon: Union Buddha Sāsana Council.

Lerner, Eric

1977 Journey of Insight Meditation: A Personal Experience of the Buddha's Way. New York: Schocken Books.

Lopez, Donald S., Jr.

1992 "Paths Terminable and Interminable." In Paths to Liberation: The Mãrga and Its Transformations in Buddhist Thought (Kuroda Institute Studies in East Asian Buddhism, no. 7), ed. Robert E. Buswell, Jr. and Robert M. Gimello, 147-192. Honolulu: University of Hawaii Press.

Mahasi Sayadaw

1971 The Satipatthana Vipassana Meditation. Translated by U Pe Thin. San Francisco: Unity Press.

Malalgoda, Kitsiri

1976 Buddhism in Sinhalese Society 1750-1900: A Study of Religious Revival and Change. Berkeley and Los Angeles: University of California Press. 
McRae, John R.

1992 "Encounter Dialogue and the Transformation of the Spiritual Path in Chinese Ch'an.' In Buswell and Gimello eds. 1992: 339-369.

Mendelson, E. Michael

1975 Sangha and State in Burma: A Study of Monastic Sectarianism and Leadership. Ed. John P. Ferguson. Ithaca and London: Cornell University Press.

Nishida Kitarō

1965-66 Nishida Kitarō zenshū. 19 vols. Tokyo: Iwanami shoten.

Nottingham, Elizabeth K.

1960 Buddhist Meditation in Burma. Rangoon: International Meditation Centre.

Nyanaponika Thera

1970 The Heart of Buddhist Meditation. New York: Samuel Weiser.

1972 The Power of Mindfulness. Mindfulness Series, no. 3. San Francisco: Unity Press.

Obeyesekere, Gananath

1970 "Religious Symbolism and Political Change in Ceylon." Modern Ceylon Studies 1 (1): 43-63.

1981 Medusa's Hair: An Essay on Personal Symbols and Religious Experience. Chicago: University of Chicago Press.

Ornstein, Robert E.

1972 The Psychology of Consciousness. San Francisco: W.H. Freeman.

Phra Acharn Maha Boowa Hyanasampanno

1976 The Venerable Phra Acharn Mun Bhüridatta Thera, Meditation Master. Trans. Siri Buddhasukh. Bangkok: Mahāmakut Rajavidyalaya Press.

Prebish, Charles S.

1975 Buddhist Monastic Discipline: The Sanskrit Prātimokșa Sūtras of the Mahāsāmghikas and Mülasarvāstivādins. University Park and London: The Pennsylvania State University Press.

Proudfoot, Wayne

1985 Religious Experience. Berkeley: University of California Press.

Rahula, Wapole

1956 History of Buddhism in Ceylon. Colombo: M.D. Gunasena.

Rorty, Richard

1979 Philosophy and the Mirror of Nature. Princeton: Princeton University Press.

Sangharakshita

1980 A Survey of Buddhism. 5th ed. Boulder: Shambhala.

Schmithausen, Lambert

1976 "On the Problem of the Relation of Spiritual Practice and Philosophical Theory in Buddhism." In German Scholars on India vol. 2, 235-250. Bombay: Nachiketa.

1981 "'On Some Aspects of Descriptions or Theories of 'Liberating Insight' and 'Enlightenment' in Early Buddhism.' In Studien zum Jainismus und Buddhismus, ed. Klaus Bruhn and Albrecht Wezler, 199-250. Wiesbaden: Franz Steiner.

Scholem, Gershom G.

1961 “Zen-Nazism?"' Encounter 16 (2): 96.

1965 On the Kabbalah and Its Symbolism. Trans. Ralph Manheim. New York: Schocken Books.

Schopen, Gregory

1975 "'The Phrase 'sa prthivīpradeśas caityabhüto bhavet' in the Vajracchedikā: Notes on the Cult of the Book in the Mahāyāna." Indo-Iranian Journal 17: 147-181. 
Shapiro, Deane H., Jr.

1984 "Overview: Clinical and Physiological Comparison of Meditation with Other Self-Control Strategies." In Meditation: Classic and Contemporary Perspectives, ed. Deane H. Shapiro, Jr. and Roger N. Walsh, 5-12. New York: Aldine de Gruyter.

Sharf, Robert H.

1989 "Being Buddha: A Performative Approach to Ch'an Enlightenment." Paper presented at the annual meeting of the American Academy of Religion, Anaheim, November 20, 1989.

1994 "Visualization and Mandala in Shingon Buddhism." Paper presented at the annual meeting of the American Academy of Religion, Chicago, November 21, 1994.

1995a "The Zen of Japanese Nationalism." In Curators of the Buddha: The Study of Buddhism Under Colonialism, ed. Donald S. Lopez Jr. Chicago: University of Chicago Press.

1995b "Whose Zen? Zen Nationalism Revisited." In Rude Awakenings: Zen, the Kyoto School, and the Question of Nationalism, ed. James W. Heisig, and John C. Maraldo, 40-51. Honolulu: University of Hawaii Press.

n.d. 'Sanbōkyōdan: Zen and the Way of the New Religions.' Japanese Journal of Religious Studies (forthcoming).

Shattock, E.H.

1972 An Experiment in Mindfulness. New York: Samuel Weiser.

Shear, Jonathan

1994 "On Mystical Experiences as Empirical Support for the Perennial Philosophy." Journal of the American Academy of Religion 62 (2): 319-342.

Smart, Ninian

1977 "The Exploration of Mysticism." In Mystics and Scholars, ed. Harold Coward and Terence Penelhum, 63-70. Toronto [?]: Canadian Corporation for Studies in Religion.

Sole-Leris, Amadeo

1986 Tranquillity and Insight: An Introduction to the Oldest Form of Buddhist Meditation. Boston: Shambhala Publications.

Spiro, Melford E.

1970 Buddhism and Society: A Great Tradition and Its Burmese Vicissitudes. New York: Harper and Row.

Strong, John S.

1979 "The Legend of the Lion-Roarer: A Study of the Buddhist Arhat Pindola Bhāradvāja.' Numen 26 (1): 50-88.

Stuart-Fox, Martin

1989 "Jhāna and Buddhist Scholasticism." Journal of the International Association of Buddhist Studies 12 (2): 79-110.

Suzuki, Daisetz Teitaro

1963 Outlines of Mahayana Buddhism. New York: Schocken Books.

Swearer, Donald

1970 "Lay Buddhism and the Buddhist Revival in Ceylon." Journal of the American Academy of Religion 38 (3): 255-275.

Tambiah, Stanley Jeyaraja

1970 Buddhism and the Spirit Cults in North-east Thailand. Cambridge Studies in Social Anthropology, no. 2. Cambridge: Cambridge University Press.

1976 World Conqueror and World Renouncer: A Study of Buddhism and Polity in 
Thailand against a Historical Background. Cambridge Studies in Social Anthropology, no. 15. Cambridge: Cambridge University Press.

1984 The Buddhist Saints of the Forest and the Cult of Amulets: A Study in Charisma, Hagiography, Sectarianism, and Millennial Buddhism. Cambridge Studies in Social Anthropology, no. 49. Cambridge: Cambridge University Press. Vimalo Bhikkhu

n.d. "Awakening to the Truth." Mimeograph copy.

Walsh, Roger N.

1984 “An Evolutionary Model of Meditation Research." In Meditation: Classic and Contemporary Perspectives, ed. Deane H. Shapiro, Jr. and Roger N. Walsh, 24-32. New York: Aldine de Gruyter.

1993 "Phenomenological Mapping and Comparisons of Shamanic, Buddhist, Yogic, and Schizophrenic Experiences." Journal of the American Academy of Ward, Tim Religion 61 (4): 739-769.

1990 What the Buddha Never Taught. Toronto: Somerville House.

Woodward, F.L., trans.

1970 Manual of a Mystic, Being a Translation from the Pali and Sinhalese Work Entitled The Yogavachara's Manual. London: Pali Text Society. 